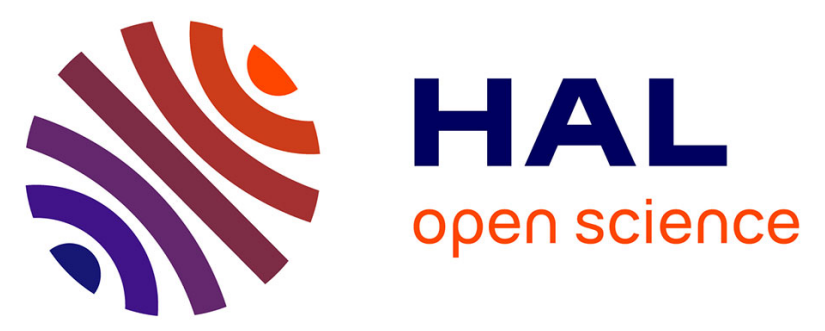

\title{
Structural organization and tooth development in a Homo aff. erectus juvenile mandible from the Early Pleistocene site of Garba IV at Melka Kunture, Ethiopian highlands
}

Clément Zanolli, M. Christopher Dean, Yared Assefa, Priscilla Bayle, José Braga, Silvana Condemi, Metasebia Endalamaw, Blade Engda Redae, Roberto Macchiarelli

\section{- To cite this version:}

Clément Zanolli, M. Christopher Dean, Yared Assefa, Priscilla Bayle, José Braga, et al.. Structural organization and tooth development in a Homo aff. erectus juvenile mandible from the Early Pleistocene site of Garba IV at Melka Kunture, Ethiopian highlands. American Journal of Physical Anthropology, 2017, 162 (3), pp.533-549. 10.1002/ajpa.23135 . hal-02296656

\section{HAL Id: hal-02296656 https://hal.science/hal-02296656}

Submitted on 26 Feb 2021

HAL is a multi-disciplinary open access archive for the deposit and dissemination of scientific research documents, whether they are published or not. The documents may come from teaching and research institutions in France or abroad, or from public or private research centers.
L'archive ouverte pluridisciplinaire HAL, est destinée au dépôt et à la diffusion de documents scientifiques de niveau recherche, publiés ou non, émanant des établissements d'enseignement et de recherche français ou étrangers, des laboratoires publics ou privés. 


\section{Structural Organization and Tooth Development in a Homo aff. erectus Juvenile Mandible from the Early Pleistocene Site of Garba IV at Melka Kunture, Ethiopian Highlands}

Clément Zanolli, ${ }^{1 *}$, M. Christopher Dean, ${ }^{2}$ Yared Assefa, ${ }^{3}$ Priscilla Bayle, ${ }^{4}$ José Braga, ${ }^{1}$ Silvana Condemi, ${ }^{5}$ Metasebia Endalamaw, ${ }^{3}$ Blade Engda Redae, ${ }^{3}$ and Roberto Macchiarelli ${ }^{6,7}$

${ }^{1}$ Laboratoire AMIS, UMR 5288 CNRS, Université Toulouse III Paul Sabatier, Toulouse, France

${ }^{2}$ Department of Cell and Developmental Biology, University College, London, UK

${ }^{3}$ Authority for Research and Conservation of Cultural Heritage (ARCCH), National Museum of Ethiopia, Addis Ababa, Ethiopia

${ }^{4}$ Laboratoire PACEA, UMR 5199 CNRS, Université de Bordeaux, Bordeaux, France

${ }^{5}$ Laboratoire ADES, UMR 7268 CNRS, Université d'Aix-Marseille, Marseille, France

${ }^{6}$ Laboratoire HNHP, UMR 7194 CNRS, Muséum national d'Histoire naturelle, Paris, France

${ }^{7}$ Unité de Formation Géosciences, Université de Poitiers, Poitiers, France

KEY WORDS Calabrian Stage; Homo aff. erectus; juvenile mandible; dentition; Melka Kunture

Grant sponsors: French CNRS; University of Rome La Sapienza; International Centre of Theoretical Physics, Trieste.

*Correspondence to: Clément Zanolli, Laboratoire AMIS, UMR 5288 CNRS, Université Toulouse III Paul Sabatier, France.

E-mail: clement.zanolli@gmail.com 


\section{ABSTRACT}

Objectives: The immature partial mandible GAR IVE from the c. 1.7 Ma old Garba IV site at Melka Kunture (Upper Awash Basin, Ethiopia), the earliest human representative from a mountain-like environment, represents one of the oldest early Homo specimens bearing a mixed dentition. Following its first description (Condemi, 2004), we extended the analytical and comparative record of this specimen by providing unreported details about its inner morphology, tooth maturational pattern and age at death, crown size and tooth tissue proportions.

Materials and Methods: The new body of quantitative structural information and virtual imaging derives from a medical CT record performed in 2013.

Results: Compared to the extant human condition and to some fossil representatives of comparable individual age, the GAR IVE mandible reveals absolutely and relatively thick cortical bone. Crown size of the permanent lateral incisor and the canine fit the estimates of $H$. erectus s.l., while the $\mathrm{dm} 2$ and the M1 more closely approach those of $H$. habilis-rudolfensis. Molar crown pulp volumes are lower than reported in other fossil specimens and in extant humans. The mineralization sequence of the permanent tooth elements is represented four times in our reference sample of extant immature individuals $(\mathrm{N}=795)$.

Conclusions: The tooth developmental pattern displayed by the immature individual from Garba IV falls within the range of variation of extant human populations and is also comparable with that of other very young early fossil hominins. Taken together, the evidence presented here for mandibular morphology and dental development suggest GAR IVE is a robust 2.5-3.5 year old early Homo specimen. 
Melka Kunture is a complex of archaeological and paleontological sites of the Ethiopian highlands (c. $2000 \mathrm{~m}$ asl) extending along the Upper Awash Valley on the western shoulder of the Rift Valley, $50 \mathrm{~km}$ south of Addis Ababa (Chavaillon and Piperno, 2004a). Following its first identification in 1963, within the development of a UN water program, preliminary archaeological survey was undertaken one year later by G. Bailloud (Bailloud, 1965). From 1965 to 1998 the activity of the French Archaeological Mission was directed by J. Chavaillon (Chavaillon et al., 1979; Chavaillon and Piperno, 2004b). Since 1999, research in the area has been carried on by the Italian Archaeological Mission at Melka Kunture and Balchit (Chavaillon and Piperno, 2004b; Mussi et al., 2014; http://www.melkakunture.it/).

The sites at Melka Kunture (Atebella, Garba, Gombore, Gotu, Karre, Kella, Simbiro, TcheriArussi, Tuka, Weraba, Wofi) are named after the gullies shaped by the nearby seasonal tributaries of the Awash River (Chavaillon and Berthelet, 2004; Gallotti, 2013: fig. 1). Their fluviallacustrine and volcanic deposits accumulated and eroded during most of the Pleistocene in a semi-graben depression of c. $3000 \mathrm{~km}^{2}$ whose southwestern edge is the Melka fault (Taieb, 1967; Kieffer et al., 2002, 2004; Bardin et al., 2004; Chavaillon and Piperno, 2004a; Raynal and Kieffer, 2004; Raynal et al., 2004; Piperno et al., 2009; Morgan et al., 2012; Gallotti et al., 2014; Tamrat et al., 2014).

Relative and absolute chronological assessment of the alluvial and tuffaceous deposits outcropping in the nearly $100 \mathrm{~km}^{2}$ area of Melka Kunture have been established on the ground of litho- and archaeostratigraphic unit correlations (Taieb, 1967, 1971; Chavaillon and Taieb, 1968; Chavaillon et al., 1979; Kieffer et al., 2004; Raynal et al., 2004) and by $\mathrm{K} / \mathrm{Ar}$ and ${ }^{40} \mathrm{Ar} /{ }^{39} \mathrm{Ar}$ radiometric ages thanks to the presence of volcanic deposits (in Morgan et al., 2012). Supported by an updated magnetostratigraphic record (Tamrat et al., 2014), available evidence shows that the exposed sections cover approximately the entire Calabrian Stage (Early Pleistocene), from the top of the normal polarity Olduvai Subchron to the early Brunhes (Morgan et al., 2012; Tamrat et al., 2014). The archaeological record starts at c. 1.7 Ma with the Oldowan levels of Karre I, Gombore I, Gombore I $\gamma$, and Garba IVE-G (Piperno et al., 2009; Morgan et al., 2012; Gallotti, 2013; Gallotti and Mussi, 2015), while the first evidence of Acheulean from Garba IVD is referred to c. 1.5 Ma (Gallotti, 2013). The occurrence of the Acheulean then lasts nearly one million years (Chavaillon and Berthelet, 2004; Gallotti et al., 2010, 2014). So far, the early Middle Stone Age is represented at the site of Garba IIIB (Mussi et al., 2014), while Late Stone 
Age occurrences lack geochronological resolution because volcanic ashes did not cover the Middle-Late Pleistocene sites (Hivernel-Guerre, 1976; Chavaillon et al., 1979; Chavaillon and Berthelet, 2004; Mussi et al., 2014).

Besides Homo (see below), the mammal fossil assemblage from Melka Kunture, particularly rich at Garba and Gombore, includes bovids (notably, Alcelaphini and some Antilopini and Reduncini), hippopotamids, equids, suids, giraffids, and some proboscideans, rhinocerontids, carnivores and non-hominin primates (Oussedik, 1976; Geraads, 1979, 1985; Chavaillon and Berthelet, 2004; Geraads et al., 2004a; Gallotti et al., 2010, 2014; Beaudet et al., 2015). This assemblage associates Hippopotamus sp. (cf. amphibious and cf. aethiopicus) and other artiodactyls indicative of relatively wet grasslands (Kobus) along with grazer (e.g., Connochaetes, Damaliscus) and primate taxa (Theropithecus) more commonly found in drier open environments (Geraads et al., 2004a, b; Beaudet et al., 2015). While the latter scenario is also consistent with information from the microfauna (Sabatier, 1980-82; Geraads et al., 2004b; Gallotti et al., 2010) and with some biogeochemical (Bocherens et al., 1996) and palynological data (Bonnefille, 1976) supporting the presence of spread C4 grasslands in the area across most Early to early Middle Pleistocene (in Morgan et al., 2012), paleoecological interpretations at Melka Kunture require caution, as the proportions of mammal taxa, notably the ungulates, reflect strong taphonomic biases (Gallotti et al., 2010: 298). However, a more recent palynologically based paleoenvironmental reconstruction (Mussi et al., 2015) supports a landscape across most of the Pleistocene compatible with the so-called "dry evergreen afromontane forest and grassland complex" (Friis et al., 2011; Kebede et al., 2013), with no evidence whatsoever of vegetation encountered in the present-day Rift Valley and of any savannah tree species (Mussi et al., 2015).

The human fossil record from Melka Kunture (Coppens, 2004; updating in Mussi et al., 2014) consists so far of the following seven remains: an immature partial mandible (MK 81 GAR IVE 0043) from Garba IV (Condemi, 2004; Zilberman et al., 2004a, b; Zanolli et al., 2014a) and an adult distal humerus (MK 76 GOM IB 7594) from Gombore I (Chavaillon et al., 1977; Senut, 1979; Carretero et al., 2009; Puymerail et al., 2014; Di Vincenzo et al., 2015), both associated with Oldowan industries; two adult cranial portions (MK 73 GOM II 6169 and MK 76 GOM II 576) from Gombore II (Chavaillon et al., 1974; Chavaillon and Coppens, 1986; Profico et al., 2016), associated with a middle Acheulean industry; and three juvenile to adult cranial fragments from Garba III (MK 78 GAR III A4-W9 n. 1918, MK 78 GAR III B3-A13 n. 1656-1919, and 
MK 78 GAR III A4-W9 n. 1917) associated with an early Middle Stone Age industry (Chavaillon et al., 1987; Mussi et al., 2014).

The immature right mandibular portion MK 81 GAR IVE 0043 (hereafter GAR IVE) was discovered in situ in 1981 during excavation of the archaeostratigraphic unit E of Garba IV, a site located on the right bank of the Awash, whose Calabrian deposits belong to the lowest part of the Melka Kunture Formation (Kieffer et al., 2002, 2004; Raynal and Kieffer, 2004; Raynal et al., 2004; Gallotti, 2013; Gallotti and Mussi, 2015). Started in 1972 (Chavaillon and Piperno, 1975), investigations at Garba IV revealed the presence of several archaeological horizons within a stratigraphic sequence of three units almost entirely sandwiched within two tuff layers identified along the Garba gully, tuff A0 and the 'Grazia tuff' (Raynal et al., 2004), which have been

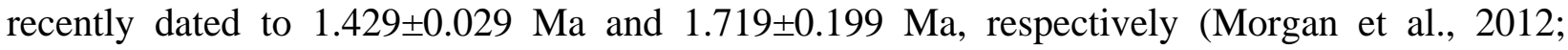
Tamrat et al., 2014). More specifically, the level E (Piperno and Bulgarelli-Piperno, 1975; Piperno and Bulgarelli, 2004; Piperno et al., 2004a, b, c, d; Gallotti, 2013), whose polarity is normal (Tamrat et al., 2014: fig. 8), lies immediately below the 'Grazia tuff' (Raynal et al., 2004; Morgan et al., 2012: fig. 2a; Gallotti, 2013: fig. 2c; Gallotti and Mussi, 2015: fig. 3). Accordingly, the age of the specimen GAR IVE should be around/slightly older than $1.7 \mathrm{Ma}$, thus nearly contemporaneous to specimens such as KNM-ER 1805 from the Karari Ridge at Koobi Fora, Kenya (McDougall et al., 2012).

Firstly reported by Condemi (2004; http://geoserver.itc.nl/melkakunture/biblio/monograph/melka-687.pdf) and attributed to $H$. erectus/ergaster because of its closer morphological and dimensional similarities to penecontemporaneous $H$. aff. erectus specimens from the Turkana basin (see also Coppens, 2004), notably the subadult mandibles KNM-ER 820 and KNM-WT 15000 and, to some extent, the adult representative ER 992 (rev. and references in Wood and Leakey, 2011), GAR IVE is one of the few dentognathic remains from the Early Pleistocene African human record sampling a child. It is also noteworthy that, together with the c. $1.4 \mathrm{Ma} \mathrm{H}$. erectus craniodental remains from the c. $1500 \mathrm{~m}$ asl site of Konso, at the southwestern end of the Main Ethiopian Rift (Suwa et al., 2007), this specimen represents the oldest of any human remains from a mountain-like environment.

GAR IVE represents a right mandibular corpus preserved between the central deciduous incisor (di1) broken socket and the first permanent molar (M1) crypt. It bears a heavily worn first 
deciduous molar (dm1) and a relatively unworn second deciduous molar ( $\mathrm{dm} 2)$, both in occlusion. Part of the developing crowns of the lateral permanent incisor (I2) and canine (C), as well as the completely formed but still unerupted M1 crown, are also visible. A radiographic analysis performed by Condemi (2004) evidenced the presence of the third and fourth premolars (P3 and P4) still in their crypt. Based on dental development and wear stages, an age at death of 3-4 years has been suggested for this individual (Condemi, 2004). Scanning electron microscopy (SEM) of the outer enamel texture of the $\mathrm{dm} 1, \mathrm{dm} 2$ and M1 suggests the individual may have experienced an inherited pathological condition of enamel formation known as amelogenesis imperfecta (Zilberman et al., 2004a, b). However, while these first studies on GAR IVE presented basic information on this unique fossil, there is still extremely limited data available regarding the structural organization and about skeletal and dental development of early Homo immature specimens (e.g., Dean and Smith, 2009; Bermúdez de Castro et al., 2010; Dean, 2016).

By using imaging techniques applied to an X-ray computed tomography record of GAR IVE, the aims of the present study are (i) to integrate details of its outer and inner structural morphology; (ii) to define the developmental stage of each virtually extracted tooth and to estimate the most likely age at death of this child based on modern human standards; (iii) to comparatively assess the size of all, erupted and unerupted, measurable crowns; and (iv) to tentatively quantify crown tooth tissue proportions in the deciduous second and permanent first molars.

\section{MATERIALS AND METHODS}

Observations of the external morphology of GAR IVE were carried out in 2012 and 2013 at the Department of Paleoanthropology of the National Museum of Ethiopia, Addis Ababa, where the specimen is permanently stored, by using a Nikon SMZ645 stereomicroscope and a Keyence VHX-600 digital microscope equipped by a 2.11 Mp CCD camera. In November 2013, the

specimen was preliminarily detailed by X-ray computed tomography (CT) at the Wudassie Diagnostic Centre of Addis Ababa. The acquisitions were performed with a Philips Brilliance16 equipment according to the following parameters: $140 \mathrm{kV}$ voltage, $100 \mu \mathrm{A}$ current, $1.76 \mathrm{~s}$ exposition time per projection. The final volume was reconstructed with a voxel size of 
130x130x300 $\mu \mathrm{m}$. Subsequent 2D-3D elaborations (quantitative virtual imaging and morphometrics) were performed at the ICTP of Trieste.

The limited resolution of the CT record available to us currently precludes any investigation of the enamel microstructure. Accordingly, at this stage of the study, which mainly focuses on the previously unreported inner structure of the specimen with the primary aim of refining the overall maturational stage of this juvenile individual, no (re)evalution was attempted regarding the diagnosis of amelogenesis imperfecta proposed by Zilberman et al. (2004a, b). Nonetheless, we note that, irrespective of the nature of such irregularities at the enamel surface (Hillson, 2005: 168-169) which have been recently observed also in some South African australopith molars (Towle et al., 2016), in terms of morphology and proportions, all tooth crowns lack any evidence of anomalous features at mesostructural scale (Figs. 1, 3, 4). A semi-automatic threshold-based segmentation with manual corrections was carried out following the half-maximum height method (HMH; Spoor et al., 1993) and the region of interest thresholding protocol (ROI-Tb; Fajardo et al., 2002) and by taking repeated measurements on different slices of the virtual stack using Avizo v.6.2. (Visualization Sciences Group Inc.) and ImageJ v.1.48 (Schneider et al., 2012).

Besides detailed analytical and comparative information on the outer aspect of the GAR IVE partial mandible provided by Condemi (2004), here we specifically investigated the buccolingual cross-sectional cortical bone distribution assessed at the $\mathrm{dm} 2$ level. For comparative purposes, we used the high resolution microtomographic-( $\mu \mathrm{CT}$-)based record of three human immature mandibles available in our files representing: the 2.5-3 years old Neanderthal child from Roc de Marsal (OIS 4; Bayle et al., 2009a, 2010; NESPOS Database, 2015); the 3-4 years old late Upper Paleolithic child La Madeleine 4 (OIS 1-2; Bayle et al., 2009b, 2010; NESPOS Database, 2015); and a 3.5-4 years old extant European individual (spec. EH-UdP; Bayle et al., 2010). Given some differences in preservation condition among the specimens and the structural variation of the cortical shell at this level, in all cases we only considered the bony portion immediately below the thinner perialveolar area (see Fig. 2A). Site-specific cortical thickness variation across each section and percent cortical area were assessed using the software package MPSAK v.2.9 (available in Dean and Wood, 2003). For cortical thickness, we automatically performed 3242 linear measurements on GAR IVE (investigated cross-sectional perimeter: $43.3 \mathrm{~mm}$; total area: 
$\left.215.9 \mathrm{~mm}^{2}\right)$, 557 on Roc de Marsal $\left(31.6 \mathrm{~mm} / 132.5 \mathrm{~mm}^{2}\right), 533$ on La Madeleine 4 (31.6 $\left.\mathrm{mm} / 111.6 \mathrm{~mm}^{2}\right)$, and 515 measurements on the extant human specimen $\left(26.2 \mathrm{~mm} / 90 \mathrm{~mm}^{2}\right)$.

While the resolution of the currently available CT record does not allow for any unambiguous distinction between enamel and dentine, we were able to virtually segment, extract and assess each tooth element. We then combined such information with direct observations performed on the crown morphology visible on the original specimen.

The Bayesian analysis of the dental maturational sequence of GAR IVE is based on a toothby-tooth evaluation of the stage of dental mineralization of the teeth according to the scoring system (crown and root calcification stages) established by Demirjian et al. (1973) for the permanent teeth, and by Liversidge and Molleson (2004) for the deciduous teeth, modified and adapted by Bayle et al. (2009a). The estimation relies upon the CT-based examination of the teeth preserved in situ within the mandible. The sequence composed by the I2, C, P3, P4 and M1 has been compared to those assessed following the same scoring methods on a radiographic and CT reference sample of 795 living humans (408 females and 387 males) of African, European, and Middle Eastern origins, aged 1-8 years and distributed as follows: 1-2 years ( $\mathrm{N}=14$ individuals), 2-3 years $(\mathrm{N}=21), 3-4$ years $(\mathrm{N}=74), 4-5$ years $(\mathrm{N}=119), 5-6$ years $(\mathrm{N}=153), 6-7$ years $(\mathrm{N}=178)$, and 7-8 years (N=236) (Braga and Heuzé, 2007; Bayle et al., 2009a, b, 2010; original data). The statistical analysis of each dental mineralization sequence was carried out by applying the method developed by Braga and Heuzé (2007), using Bayes's rule of conditional probability (Vieland, 1998; Aitken and Taroni, 2004), with teeth being considered as statistically dependent units and prior probabilities uniform.

Description of the nonmetric crown outer topography follows Scott and Turner (1997) and is based on the Arizona State University Dental Anthropology System (ASUDAS) scores (Turner et al., 1991). Maximum mesiodistal (MD) and buccolingual (BL) diameters of the two deciduous and the first permanent molars were provided by Condemi (2004: tab. 4) and discussed in a wide comparative context. However, given the position in the alveolar bone of the growing M1, both values were considered underestimated (Condemi, 2004: 694). Accordingly, following the 3D reconstruction and virtual extraction of this crown, we refined such measurements and updated their comparisons. By using the same imaging techniques, we revised the metric record of the $\mathrm{dm} 2$ and the M1 and provide here original information on the previously unreported lateral incisor and canine crowns and compare their size with the figures from a number of fossil and 
recent human specimens/samples (see Supporting Information). We also digitally measured the crown height of the $\mathrm{I} 2, \mathrm{C}$, and $\mathrm{M} 1$ as the maximum projected distance from the cervix to the highest point on the crown.

Because of the advanced degree of wear affecting the dm1 (stage 6 following Smith, 1984; see below), only the crowns of the $\mathrm{dm} 2$ and of the unworn M1 were virtually isolated from their roots for quantifying tissue proportions based on the best-fit plane of the cervical line. The crown pulp volume $(\mathrm{Vcp})$ and total crown volume $(\mathrm{Vc})$ were estimated and the percent of coronal volume that is pulp was then calculated $(\mathrm{Vcp} / \mathrm{Vc})$. Tissue proportions in GAR IVE were then directly compared with the microtomographic-based evidence available to us from: the c. 1 Ma $H$. erectus/ergaster M1/2 specimen MA 93 from the Eritrean Danakil (Zanolli et al., 2014b); the late Early-early Middle Pleistocene H. erectus dm2 PCG.2 from the Sangiran Dome, Java (Zanolli et al., 2012); a sample of $6 \mathrm{dm} 2 \mathrm{~s}$ and $11 \mathrm{M} 1 \mathrm{~s}$ of European Neanderthals from La Chaise-deVouthon Abri Suard, Krapina, Combe Grenal, and Roc de Marsal (Macchiarelli et al., 2006, 2013; Olejniczak et al., 2008; Bayle et al., 2009a, 2010; Kupczik and Hublin, 2010; Zanolli et al., 2012, 2014a; NESPOS Database, 2015); 3 dm2s and 1 M1 sample of the two European Upper Paleolithic specimens of Lagar Velho and La Madeleine (Bayle, 2008; Bayle et al., 2009b, 2010; NESPOS Database, 2015); and a nearly unworn sample of $7 \mathrm{dm} 2 \mathrm{~s}$ and $11 \mathrm{M} 1 \mathrm{~s}$ of recent/extant Europeans (Bayle, 2008; Olejniczak et al., 2008; Bayle et al., 2010; Zanolli et al., 2012, 2014a; and original data).

Intra- and inter- tests for accuracy of the estimates were run by two observers. Linear, surface, and volumetric measurements provided for both tests differences of $3.6 \%$, on average, the highest recorded difference reaching $6 \%$ for the variable Vcp.

\section{RESULTS}

\section{External morphology and cross-sectional structure}

The specimen GAR IVE represents a $58 \mathrm{~mm}$ long incomplete but relatively well preserved and robust right mandibular corpus fragment lacking the ramus and the symphysis (extended description and comparisons in Condemi, 2004). It still preserves the fully erupted $\mathrm{dm} 1$ and $\mathrm{dm} 2$, as well as five unerupted permanent teeth (I2, C, P3, P4, and M1), three of them (I2, C and M1) 
visible at the level of the anterior and posterior breakages of the corpus (Fig. 1). On the lateral aspect, there is an $8.5 \mathrm{~mm}$ high and $6.5 \mathrm{~mm}$ large hole below the dm1 (Fig. 1A, E), which likely represents a carnivore tooth-mark (Zanolli et al., 2014a). Its inspection by low magnification microscopy shows slightly sunken morphology of its sub-rectangular bony rim, reduction inwards of its diameters, and the presence on the distal aspect of traces of the nerve canal associated to the mental foramen, the latter being no longer preserved (cf. Condemi, 2004). Interestingly, CT-based imaging reveals that, whatever its nature, the impact reached the buccal aspect of the crypt lodging the growing P3 crown, which bears a distinct transverse fracture (Figs. 1A, 1B, 3), but did not reach the inner (lingual) mandibular wall (Fig. 1B). At the dm2 level, height and breadth (width) of this mandibular body correspond to $20.1 \mathrm{~mm}$ and $14.5 \mathrm{~mm}$, respectively (Condemi, 2004). Despite damage to the region of the mental formamen, it seems clear GAR IVE, like Ledi-Geraru LD 350, from Ethiopia, and other early Homo mandibles (Villmoare et al., 2015), lacks the lateral corpus hollow in which the mental foramen is located, which distinguishes $A$. afarensis mandibles across their size range.

Comparative cortical bone distribution and proportions across the mandibular buccolingual virtual section through the mid $\mathrm{dm} 2$ in GAR IVE, in a Neanderthal, a European Upper Paleolithic, and in an extant human representative, all sampling juvenile individuals whose estimated age ranges from c. 2.5 to c. 4 years, are shown in Figure 2. At this cross-sectional level, the Ethiopian specimen exhibits the largest dimensions and absolute greatest robustness of the

corpus outline, notably with respect to the condition displayed by the extant child used in this study (Fig. 2A). GAR IVE also shows at all sites absolutely and relatively thicker cortical bone (average: $2.4 \pm 0.3 \mathrm{~mm}$ ) than measured in Roc de Marsal (av.: 1.8 $\pm 0.6 \mathrm{~mm}$ ), La Madeleine (av.: 1.6 $\pm 0.5 \mathrm{~mm}$ ), and in the extant human mandible (av.: 0.9 $\pm 0.2 \mathrm{~mm}$ ) (Fig. 2B). Percent cortical area in GAR IVE (42.3\%) also exceeds the estimates obtained for all three comparative specimens $(40.5 \%, 38.4 \%$, and $23.6 \%$, respectively).

\section{Dental developmental stages}

At the time of death of the juvenile individual sampled by GAR IVE, the dm1 was in occlusion and heavily worn (stage 6; Smith, 1984), with most of the occlusal enamel removed, more so distally than mesially, but still preserving a thin peripheral enamel ring (c. $0.4 \mathrm{~mm}$ thick 
lingually and $0.8 \mathrm{~mm}$ buccally; contra Zilberman et al., 2004b) (Figs. 1, 3, 4). It shows completed mesial and distal roots, with two separated pulp canals in the mesial root but with a reduced pulp cavity distally and an occluded root canal in the distal root (Fig. 3). Both roots show signs of apical resorption in a manner that reflects the P3 crypt outline beneath these roots (Table 1, Fig. 3). However, as $4 \mathrm{~mm}$ of each root are exposed above the alveolar crestal bone compared with only $2 \mathrm{~mm}$ exposed on the $\mathrm{dm} 2$, it seems that the $\mathrm{dm} 1$ was slightly extruded from its socket post mortem, as evidenced by the raised contact facet with the dm2 distally.

The dm2 also was already in occlusion at the time of death, but it shows considerably less wear compared to the dm1 (stage 2; Smith, 1984), with small wear facets only appearing on the buccal cusps and on the entoconid (Figs. 1, 3, 4). Its two widely mesiodistally spaced roots, with open apexes, are incompletely formed (Table 1, Fig. 3). The pulp chamber displays five well developed horns corresponding to each cusp. There are two separate root canals (buccal and lingual) in the mesial root. Only a single, larger and flat, canal is visible in the distal root (Fig. 3).

The I2 is preserved within the alveolar bone, its incisal edge lying c. $2 \mathrm{~mm}$ below the alveolar bone margin (Figs. 1E, 4). Measured from the incisal edge to the farthest point on the base margin, the crown is $9.4 \mathrm{~mm}$ high. It is complete down to the cement-enamel junction and beginning of root formation mesially where there is c. $3.8 \mathrm{~mm}$ root dentine formed, but only c. $1.8 \mathrm{~mm}$ distally (Table 1, Fig. 3). Its pulp cavity is finger-shaped (Fig. 3).

The permanent $\mathrm{C}$ germ lies low in the mandibular corpus, with its tip approximately $1.5 \mathrm{~mm}$ above the level of the base of the I2 germ, and approximately $2.5 \mathrm{~mm}$ below the level of the $\mathrm{dm} 1$ root apexes (Figs. 1D-F, 4). The germ measures $7.5 \mathrm{~mm}$ high from cusp tip to crown base, which may represent $2 / 3$ or less of the final completed crown height (Table 1, Fig. 3). Its pulp cavity only shows a rounded horn (Fig. 3).

The P3 germ, lodged in its crypt under the dm1, measures $7.6 \mathrm{~mm}$ from cusp tip to base. It lies higher in the alveolar bone than both the canine germ, mesially, and the P4 germ, distally (Fig. $1 \mathrm{D}-\mathrm{F})$. Its base is at the level of the upper margin of the penetrating tooth-mark present on the lateral aspect of the mandibular fragment, and at the level of the distal root apex of the $\mathrm{dm} 2$, distally (Fig. 1E). Its cusp tip lies at the level of the mid-crown of the I2. The buccal and lingual cusps of this germ lie directly in the buccolingual plane (Fig. 1F). Crown formation is complete at the occlusal surface and active extension and convergence towards the cervical region is seen (Table 1, Fig. 3). The pulp chamber only shows a pulp horn under the protoconid (Fig. 3). 
The P4 germ, measuring $5.4 \mathrm{~mm}$ from the cusp tip to the base margin, lies in the mandibular corpus at approximately the same level as the canine germ, but now with its occlusal surface facing buccally (presumably having rotated post mortem). It is positioned at the same level of the tooth-mark puncture, but distal to it (Fig. 1D-F). It still lies low between the apical portions of the $\mathrm{dm} 2$ roots. The outline of the occlusal surface is complete, but the lateral enamel extension towards the cervical region had barely begun (Table 1, Fig. 3). The pulp chamber roof only shows a low relief, but with evidence of a forming protoconid pulp horn (Fig. 3).

The M1 is still contained within its bony crypt within the corpus, but is partially visible in lingual view (Figs. 1B-E, 4). The mesial cusps lie $4 \mathrm{~mm}$ below the alveolar crestal margin, just distal to the mid-point of the distal root of the $\mathrm{dm} 2$, and at the level of the inferior aspect of the bifurcation of the mesial and distal roots of the $\operatorname{dm} 2$ (equal also to approximately the level of the middle of the I 2 crown, anteriorly). The M1 crown is complete and measures $7.4 \mathrm{~mm}$ high from the mesial cusps to the mesiobuccal cervix. The pulp chamber roof displays five well developed horns corresponding to each occlusal cusp (Fig. 3). Approximately $3 \mathrm{~mm}$ of root formed below the crown distolingually were preserved (Fig. 4I), but likely slightly less than this buccally beneath the protoconid cervix. The radicular bifurcation had not begun to form at the time of death (Table 1, Fig. 3). The mandibular corpus is incomplete immediately distal to the M1 (Fig. 1B), leaving no trace of any M2 crypt.

\section{Maturational pattern}

The maturational pattern of GAR IVE and the associated scores of each tooth element are shown in Table 1, while the results of the Bayesian analysis of the mineralization sequence $(\mathrm{D} / \mathrm{C} / \mathrm{C} / \mathrm{B} / \mathrm{D})$ displayed by the preserved permanent teeth $(\mathrm{I} 2 / \mathrm{C} / \mathrm{P} 3 / \mathrm{P} 4 / \mathrm{M} 1)$ are presented in Table 2. Within the comparative sample of 795 extant children aged 1-8 years used in this study (Braga and Heuzé, 2007; Bayle et al., 2009a, b, 2010), the maturational sequence displayed by GAR IVE has been found four times. All the posterior probabilities associated with the observed combinations $(\mathrm{N}=30)$ have been efficiently calculated and all are higher than 0.75 . Although 0.75 does not represent an absolute cutoff in a continuous probability distribution (ranging from 0 to 1), probabilities higher than this formal threshold indicate very likely events, whereas values 
comprised between 0.25 and 0.75 are more likely to be associated with random events, and values lower than 0.25 with unlikely events (Braga and Heuzé, 2007).

In summary, according to the present Bayesian statistical analysis, the occurrence of a mineralization sequence like that found in GAR IVE is relatively common in extant humans of African, European, and Middle Eastern origins. In the comparative record specifically used in this study, the four children sharing their mineralization sequence with the Ethiopian fossil are one boy and three girls aged 2.67, 3.92, 4.54, and 6.42 years, respectively.

\section{Occlusal morphology and tooth crown size}

Given the amount of occlusal wear extensively affecting the dm1, a mesial fovea and a transversal ridge are the only features detectable on its crown (Fig. 4); also, its considerably reduced crown dimensions (MD: $8.8 \mathrm{~mm}$; BL: $7.6 \mathrm{~mm}$ ) cannot be used for any reliable comparison.

The dm2 crown presents five main cusps, including a large hypoconulid (C5; score 5), organized in a + occlusal groove pattern (Fig. 4). It lacks both tuberculum intermedium (C7) and tuberculum sextum (C6). The anterior fovea is sub-triangular and moderately deep (score 4). It is enclosed by a thick uninterrupted mesial marginal ridge with three accessory tubercles (Condemi, 2004) and by a low incised mid-trigonid crest (score 1B). In addition, a short ridge subdivides the mesial fovea. The entoconid, C5 and the low thick distal marginal ridge enclose a groove-shaped distal fovea. The protostylid includes two small pits located at mid-crown height at the mesiobuccal angle of the protoconid, and a V-shaped groove between protoconid and hypoconid However, in absence of information about the underlying dentine morphology and considering that all these features are at a comparable crown height, we cannot discard the possibility they result from enamel hypoplasia (see Zilberman et al., 2004a, b). Because of the extremely low degree of occlusal wear, measures of its crown size (MD: $12.0 \mathrm{~mm}$; BL: $10.2 \mathrm{~mm}$; crown height: $5.5 \mathrm{~mm})$ are highly reliable. However, the comparative dimensional record available for moderately worn Early-Middle Pleistocene human lower dm2s is rather scanty (Wood, 1991; Condemi, 2004; Moggi-Cecchi et al., 2006, 2010; Zanolli et al., 2012; see Supporting Information, Table S1). Nonetheless, in the comparative record considered in this study, we note 
that GAR IVE is intermediate between $H$. habilis-rudolfensis, South African early Homo and $H$. erectus s.l. for both MD and BL diameters (Fig. 5).

While the virtually extracted I2 crown exhibits smooth labial and lingual aspects (Fig. 3) and is thus suitable for size assessment (MD: $7.4 \mathrm{~mm}$; BL: $7.1 \mathrm{~mm}$ ), we measured but did not compare its mesiodistal diameter because of the occlusal wear commonly affecting the lower front teeth in fossil specimens (cf. Wood, 1991). Conversely, among the Early Pleistocene specimens/samples considered in our comparative analysis, its closest fits for the buccolingual diameter are the I2s from Dmanisi, Georgia (Martinón-Torres et al., 2008) and the African $H$. aff. erectus assemblage (Wood, 1991), while South African early Homo shows smaller dimensions (Moggi-Cecchi et al., 2006) and the values of H. habilis-rudolfensis, Indonesian H. erectus and H. antecessor are systematically higher (Wood, 1991; Grine and Franzen, 1994; Bermúdez de Castro et al., 1999) (Fig. 5; Table S1).

The permanent $\mathrm{C}$ crown has high and thick mesial and distal ridges, but no tuberculum dentale (Fig. 3). For its mesiodistal diameter $(8.6 \mathrm{~mm})$, it nears the average values of Chinese and African H. erectus, South African early Homo and H. habilis-rudolfensis (Wood, 1991; MoggiCecchi et al., 2006), while the canines from Dmanisi commonly display a more mesiodistally expanded crown (Martinón-Torres et al., 2008) (Fig. 5; Table S1).

Two well-developed main cusps form the growing P3 crown, and the moderately thick uninterrupted transverse crest linking them circumscribes a small mesial fossa and a larger distal fovea (Fig. 3). As noted above, its buccal aspect is transversally fractured along a plane passing laterally to the metaconid apex (Figs. 1F, 3).

While showing a slightly lower degree of maturation (Table 1), the occlusal morphology of the forming P4 crown is similar to that of the P3 (Fig. 3).

There are five main cusps forming an X-groove pattern on the M1 crown, including a large hypoconulid (C5; score 5) (Figs. 3, 4). This crown is absolutely and relatively large (MD: 13.7 $\mathrm{mm}$; BL: $12.2 \mathrm{~mm}$ ). In the comparative context considered in the present study (Fig. 5; Table S1), its best average dimensional fit are South African early Homo (Wood, 1991; Moggi-Cecchi et al., 2006, 2010) and the H. habilis-rudolfensis assemblage (Wood, 1991; Leakey et al., 2012), but for both diameters it falls near the upper limits of variation displayed by African and Eurasian H. erectus s.l. and African H. heidelbergensis (Wood, 1991; Widianto, 1993; Kaifu et al., 2005; Suwa et al., 2007; Martinón-Torres et al., 2008; Lordkipanidze et al., 2013; Zanolli, 2013; Zanolli 
et al., 2014b; Maddux et al., 2015), and also exceeds the estimates available for $H$. antecessor (Bermúdez de Castro et al., 1999, 2008).

\section{Tooth crown tissue proportions}

For the dm2 and M1 of GAR IVE, crown pulp (Vcp) and total crown (Vc) volumes and their percent ratio are given in Table 3 together with the comparative estimates available from some

Pleistocene and recent human specimens/samples. As a whole, while for $\mathrm{Vcp}$ and the $\mathrm{Vcp} / \mathrm{Vc}$ ratio the dm2 from Garba approximates the modern (fossil and recent) human figures and sets GAR IVE systematically apart from the Neanderthal values, for Vc it perfectly fits the condition displayed by the Early-early Middle Pleistocene Javanese H. erectus specimen PCG.2, from the Kabuh Formation outcropping near the Pucung village, in the southern part of the Sangiran Dome (Zanolli et al., 2012). For the M1 of GAR IVE, while it falls within the modern human range for all three variables and is also compatible with the wide range of Neanderthal variation, its crown tissue proportions differ from the condition recently described for the similarly unworn $H$. erectus/ergaster lower M1/M2 crown MA 93 from the 1.0 Ma site of Mulhuli-Amo, Danakil Eritrea (Zanolli et al., 2014b).

\section{DISCUSSION}

\section{General size and morphology}

For its external morphology and dimensions (Condemi, 2004: tab. 3), the mandibular corpus GAR IVE is similar to other early Homo juvenile representatives, such as KNM-ER 820 (Leakey and Wood, 1973) and the more fragmentary specimen KNM-ER 1507 (Leakey and Wood, 1974) from Koobi Fora (Wood and Leakey, 2011), whose age at death has been estimated at 5.3-6.5 and 4-6.1 years, respectively (in Wood, 1991). Even at a much earlier dental age, GAR IVE appears to lack the lateral corpus hollow in which the mental foramen is located in A. afarensis mandibles, and is overall more convex here, like dentally older and adult specimens such as KNM-ER 820, KNM-WT 15000, KNM-ER 992. At the dm2 level, the corpus breadth/height index of GAR IVE (72\%) is slightly higher than measured across the P4 on the adolescent 
skeleton KNM-WT 15000 (left: 66.5; Walker and Leakey, 1993) and intermediate between the values reported at the dm2 position for KNM-ER 820 (average: 67.4\%) and the more robust ER 1507 (80\%) (Wood, 1991; see tab. 19). Given that both immature specimens from East Turkana are developmentally older than GAR IVE as they share the condition of a fully erupted M1 (even if root development in KNM-ER 1507 is slightly less advanced than in ER 820; Dean, 1987), the mandible from Garba can be considered as absolutely robust. It also has large molar crowns (notably, the dm2 and the M1), whose both mesiodistal and buccolingual diameters are slightly greater than measured on average in $H$. erectus s.l., rather nearing the estimates available for $H$. habilis-rudolfensis from East Africa. Conversely, because of the still extremely limited amount of information on tooth tissue proportions in fossil Homo currently available for direct comparisons, what does seem relevant here is that both GAR IVE's molars display absolutely and relatively low crown pulp volumes. However, at this stage of the research, we cannot confidently interpret the meaning of this structural signature till some supplementary analyses at a higher resolution will be carried out on this specimen and on other penecontemporaneous immature individuals from Eastern and Southern Africa.

Interestingly, evidence for robustness in GAR IVE is compatible with recent suggestions, based on the updated analysis of the markedly robust distal humerus MK 76 GOM IB 7594 from the >1.393 $\pm 0.162 \mathrm{Ma}$ old site of Gombore I, near Garba (Di Vincenzo et al., 2015), about possible body size adaptations to harsher climatic conditions experienced by early Homo on the highlands (at altitudes around $2000 \mathrm{~m}$ ) compared to those encountered at the time in the lowland regions of East Africa (but, for compelling evidence on penecontemporaneous large body-sized humans in the rift system, see Bennett et al., 2009; Will and Stock, 2015). However, GAR IVE is smaller and less robust compared to mandibular remains from Kenya sampling immature individuals of the sympatric taxon Paranthropus boisei, like KNM-ER 1477 and KNM-ER 1820, as well as to South African specimens of P. robustus like SK 61, SK 62 and SK 63, from Swartkrans (Wood, 1991; see tabs 3 and 5 in Condemi, 2004). GAR IVE is also less robust compared to the juvenile $P$. boisei mandibular portion KGA10-570 from the $1.4 \mathrm{Ma}$ site of Konso, c. $400 \mathrm{~km}$ apart from Melka Kunture on the Ethiopian plateau (Suwa et al., 1997: tab. 1), a specimen representing a left corpus preserving a recently erupted M1 crown and P4 and M2 germs still in their crypts, displaying at M1 position a higher breadth/height index than measured on GAR IVE (Suwa, pers. comm.). 
Robusticity in GAR IVE is also revealed by its cross-sectional structure and cortical bone topographic distribution, which closely relate to the functional pattern of masticatory loads (Demes et al., 1984; Daegling, 1989; Daegling and Grine, 1991; Daegling and Hotzman, 2003; Fukase, 2007; Fukase and Suwa, 2008; Gröning et al., 2009). At the best of our knowledge, no directly comparable cortical bone thickness values measured at the same level all along the section have been made available so far for immature human fossil mandibles besides the evidence reported above for Roc de Marsal and La Madeleine. However, it is noteworthy that percent cortical area in the Ethiopian specimen, which largely exceeds the value obtained for a single extant child of comparable age used here for comparative purposes (40.5\% vs. 23.6\%), fits the proportions (cortical area/total subperiosteal area, i.e., cortical index) measured at the M1 level in extant human adult mandibles and in P. robustus (Daegling, 1989: tab. 3; Daegling and Grine, 1991: tab. 4), but exceeds those of A. africanus (Daegling and Grine, 1991: tab. 4).

A microtomographic-based virtual cross-section performed just behind the dm 2 crypt of the 5.3-6.6 years old ATD6-112A partial mandible of $H$. antecessor (individual H11; Bermúdez de Castro et al., 2010) from the late Calabrian (MIS 21) "Aurora archaeostratigraphic set" at Atapuerca Gran Dolina, Spain (Bermúdez de Castro et al., 2016), has revealed similarly thick, or even slightly thicker, cortical bone compared to the section measured at nearly the same level on GAR IVE (original unpublished record courtesy of Bermúdez de Castro and Martín-Francés Martín de la Fuente). However, while thickest cortex in both specimens is found inferiorly (2.8 $\mathrm{mm}$ in GAR IVE and $3.2 \mathrm{~mm}$ in $\mathrm{H} 11), \mathrm{H} 11$ is on average thicker lingually $(2.7 \mathrm{~mm})$ than buccally $(2.3 \mathrm{~mm})$, which is not the case in GAR IVE (2.2 mm vs. $2.4 \mathrm{~mm})$. At any rate, the lack of comparable evidence from Early Pleistocene human specimens inhibits at this stage any functional $v s$. biological interpretation of these results.

\section{Dental developmental pattern}

The Bayesian analysis of the dental developmental pattern in GAR IVE shows that it falls easily within the variation observed in extant African, European, and Middle Eastern human populations. Differences in the sequence, or pattern, of permanent tooth mineralization stages

arise between taxa because crowns and roots form over different lengths of time. During the earliest stages, as in GAR IVE before root formation begins, differences in the pattern of dental 
development are hard to discern in hominins. For example, figure 3 in Alemseged et al. (2006) shows that the pattern of the developing mandibular dentition of the $3.3 \mathrm{Ma}$ A. afarensis infant from Dikika, Ethiopia (Dik-1-1) bears a number of similarities with GAR IVE. However, despite having apparently very similar stages of permanent tooth development to GAR IVE, the permanent canine of Dik-1-1 lies much lower in the corpus, well below the level of all the other developing permanent teeth. The developing I2 in Dik-1-1 also lies well below the level of the alveolar crest in contrast to the I 2 of GAR IVE, which is only $2 \mathrm{~mm}$ beneath the alveolar crest. Moreover, the M1 in Dik-1-1, despite apparently having less root formed, appears to lie higher in the alveolus with respect to the distal dm2 root than in GAR IVE. It is the disposition of the tooth germs within the mandibles of these specimens that best distinguishes them at this early age, and not so much their pattern of tooth development.

In the future, a comparison of the values collected on GAR IVE with the tooth germ heights assessed in the early Homo partial mandibles KNM-ER 820 and KNM-ER 1507 (Wood, 1991; Wood and Leakey, 2011), both more advanced in crown height but not necessarily in proportion of the total crown formed than the Ethiopian specimen (Krovitz et al., 2003), should allow more precise and directly comparable estimates of fractional crown heights.

The pattern of development of the permanent teeth in GAR IVE also closely resembles that in some younger specimens attributed to Paranthropus, such as KNM-ER 1477, SK 64, SK 3978, TM 1536, TM 1601 (Skinner and Sperber, 1982; Dean, 1987; Smith et al., 2015). Again, this can in part be attributed to their young age where most tooth crowns are still incomplete. In general, specimens attributed to Paranthropus show a greater proportion of incisor crown complete at the time of M1 crown completion than other fossil hominins (Robson and Wood, 2008; Smith et al., 2015) and GAR IVE with its incomplete I 2 crown at the time of M1 crown completion and root initiation does not fit the typical pattern seen in Paranthropus.

Interestingly, H11 from Atapuerca Gran Dolina is another fossil hominin at a near identical stage of development to GAR IVE, with the dm2 root apex also still open and M1 crown also just complete. But M1 in H11 is slightly delayed with respect to GAR IVE, with only 0.48 to 1.58 $\mathrm{mm}$ of root formed (Bermudez de Castro et al. 2010: tab. 1), as opposed to $3 \mathrm{~mm}$ in GAR IVE. In contrast, both permanent incisor germs in $\mathrm{H} 11$ are slightly more advanced with respect to GAR IVE and have completed crowns, but with no root formed. This can be interpreted as evidence for a slowing or delay in the time taken to form M1 with respect to many earlier 
hominins (Bermudez de Castro et al., 2010). The first evidence for this in the hominin fossil record has been reported in another individual from the Gran Dolina, Atapuerca, ATD6-103 (individual H5; Gómez-Robles et al., 2007, 2011; Bermudez de Castro et al., 2010). The M1s of individual H5 had 8-9 mm of root formed with cuspal wear facets indicating only minimal attrition close to the time of gingival emergence (Bermudez de Castro et al., 2010). This amount of root formed at gingival emergence would have taken more time to form and so provides some evidence (all be it indirect) for a later age of M1 emergence than reported for earlier hominins (Dean, 2016). This would place H5 from Gran Dolina well within the modern human range for age at M1 eruption. However, while the timing of enamel growth and root growth in early Homo has been found to be faster on average than in modern humans (Dean et al., 2001, 2010; Dean and Smith, 2009; Dean and Cole, 2013), there is little evidence that there was shift to a more prolonged period of growth and dental development at the time of the transition from australopiths to early Homo (Dean 2016). Until such time, as older individuals with later stages of M2 and M3 development can be assigned a secure age at death, it remains difficult to define the origins of prolonged dental development and growth among early hominins (Dean, 2016). In acknowledgement of these limitations, it is still, however, possible to provide a broad estimate of the age at death of this individual (see discussion below). The importance of GAR IVE as a juvenile specimen is, however, not that it currently contributes to the debate about differences in dental and general growth between early Homo and australopiths; rather, it provides evidence that the disposition of developing tooth germs within the corpus and evidence that some aspects of external corpus morphology appear already at this young age to differ from those described in $A$. afarensis (Alemseged et al., 2006). This, perhaps for the first, time provides evidence in early Homo for what has been clear for some time in infant and juvenile Neanderthals, i.e., that taxonomically diagnostic morphology already exists in very young mandibles (e.g., Ponce de León and Zollikofer, 2001; Bastir et al., 2007).

\section{Individual age at death}

An age at death of 3-4 years originally suggested for GAR IVE (Condemi, 2004) may well encompass the true age at death of this specimen, but at least one younger individual (2.67 years old) in our extant reference sample shows the same developmental pattern. Perhaps, the best 
indication of the age at death of GAR IVE comes from the histological estimates of M1 crown formation times assessed in other fossil hominins. Smith et al. (2015) reported the enamel formation time in another likely early Homo M1 specimen from Sterkfontein, South Africa (StW 151; Moggi Cecchi et al. 1998). In this specimen, synchrotron imaging of enamel microstructure shows M1 took between 2.4 years (lower ml cusp) to 2.8 years (upper ml cusp) to complete. Another M1 attributed to H. erectus from Sangiran, Java (S7-37; Dean et al. 2001) took 2.47 years to complete the crown. In this specimen, $2.6 \mathrm{~mm}$ of root had formed beneath the protocone by 3.56 years of age at an average rate of $6.6 \mu \mathrm{m} /$ day. These $\mathrm{M} 1$ crown formation times seem to encompass much of the range reported for M1s in several other early hominins such as Sts 2, KNM-KP 31712 and DNH 84 (Smith et a. 2015; tabs 2, 3), but root formation rates are known to vary enormously (Dean, 2012; Dean and Cole, 2013) and remain unknown in GAR IVE.

To summarize, based on what we now know of the microstructure of other early fossil hominin M1s (in Smith et al., 2015) and in the absence of any direct histological evidence for the true crown and root formation times in GAR IVE, the age at death of this juvenile individual from Garba might well have been anything between 2.5 and 3.5 years.

\section{CONCLUDING REMARKS}

Even if they document the earliest phases in Africa of a long-term techno-cultural (Chavaillon and Piperno 2004a, 2004b) and biological adaptation to mountain ecological conditions (Mussi et al., 2015), until recently information on the Early Pleistocene human remains from the sites of Garba and Gombore, at Melka Kunture, on the Ethiopian highlands, has been poorly reported, thus legitimizing the remark that "(t)here is surprisingly limited literature on the Melka Kontouré hominids... Clearly, reappraisal of this heterogeneous assemblage is in order" (Schwartz and Tattersall, 2003: 172-173; among other titles, see also the lack of paleoanthropological information on Melka Kunture in Begun, 2013; Henke and Tattersall, 2015).

Revisited in context within the framework of an ongoing analytical revision of the whole human fossil assemblage from this important Early to Middle Pleistocene site complex (Mussi et al., 2014; Puymerail et al., 2014; Zanolli et al., 2014a; Di Vincenzo et al., 2015; Profico et al., 2016), the present study used a new X-ray computed tomography record to refine and successfully expand the original description of the c. 1.7 Ma old early Homo mandibular portion 
GAR IVE from Garba IV (Condemi, 2004; Zilberman et al., 2004a, b), notably the radiographicbased assessment of its inner structure and tooth developmental pattern (Condemi, 2004). Nonetheless, given the only modest resolution of our 2D-3D virtual reconstructions, we admit there is still much information to retrieve from this unique specimen, likely representing a 2.5 to 3.5 years old H. erectus/ergaster (Condemi, 2004; Coppens, 2004). Specifically, future research relying upon a high resolution microtomographic record should more precisely image details of the enamel-dentine junction of the deciduous second and permanent first molar crowns for comparative geometric morphometric analyses and allow the subtle quantification of tooth tissue proportions, notably in terms of enamel thickness topographic repartition (cf. Zanolli et al., 2014b).

\section{ACKNOWLEDGEMENTS}

Study developed within the activities of the Italian Archaeological Mission at Melka Kunture and Balchit (directed by M. Mussi) and supported by a grant "Grandi Scavi di Ateneo" from the University of Rome La Sapienza (to M. Mussi and A. Coppa), and by a grant "Missioni archeologiche, antropologiche, etnologiche" of the Italian Ministry for Foreign Affairs. Paleoanthropological research in Ethiopia supported by the French CNRS (to R.M.) and the International Centre of Theoretical Physics of Trieste (to C.Z.). Access to the collections and authorization for performing the CT-scan record were provided by the Authority for Research and Conservation of Cultural Heritage $(\mathrm{ARCCH})$ of the Federal Democratic Republic of Ethiopia. We are especially grateful to Y.D. Tsegaye, General Director of ARCCH and Y. Yilma, Collection directorate (Dept. of Paleoanthropology). The CT record was realized at the Wudassie Diagnostic Centre of Addis Ababa by C.Z., M.E., B.E.R. and R.M. thanks to the collaboration assured by D. Hailu (managing director). For comparative access to specimens in their care, we acknowledge S. Potze (Pretoria) and B. Zipfel (Johannesburg). For microtomographic acquisitions of comparative odontoskeletal material, we are indebted to F. de Beer, L. Bam and J. Hoffman (Necsa), K. Carlson and T. Jashashvili (Johannesburg), F. Bernardini and C. Tuniz (Trieste), the NESPOS Database, while J. Dumoncel kindly assured access to the "virtual collection" of hominin fossil specimens stored at the Univ. Toulouse III Paul Sabatier. CT-scans of extant human individuals were obtained thanks to the collaboration provided by V. Dousset, C. 
Douws and C. Thiebaut (Hopital Pellegrin, Bordeaux), by F. Brunelle, N. Boddaert and J.M. Debaets (Hospital Necker, Paris), and by J. Treil (Clinique Pasteur, Toulouse). For the assessment of the maturational tooth sequences of the extant reference sample we acknowledge M. Coquerelle (Madrid) and Y. Heuzé (Bordeaux). For scientific discussion, we are also grateful to A. Beaudet (Pretoria), J.M. Bermúdez de Castro (Burgos), L. Bondioli (Rome), J. Dumoncel (Toulouse), M. Friess (Paris), P. Lei (Toulouse), R.T. Melis (Cagliari), M. Mussi (Rome), E. Spinapolice (Cambridge). We are very grateful to G. Suwa (Tokyo), who kindly shared unpublished information on the KGA10-570 specimen from Konso, and especially to J.M. Bermúdez de Castro and L. Martín-Francés Martín de la Fuente (Burgos), for having allowed us to carry out and use for independent comparative measures original virtual slices of the $H$. antecessor specimen ADT6-112(H11).

\section{LITERATURE CITED}

Aitken C, Taroni F. 2004. Statistics and the evaluation of evidence for forensic scientists, 2nd ed. Chichester: Wiley.

Alemseged Z, Spoor F, Kimbel WH, Bobe R, Geraads D, Reed D, Wynn JG. 2006. A juvenile early hominin skeleton from Dikika, Ethiopia. Nature 443:296-301.

Bailloud G. 1965. Le gisement paléolithique de Melka-Kontouré. Cahier Istit Ethiop Archéol Addis Abeba 1:1-37.

Bardin G, Raynal J-P, Kieffer G. 2004. Drainage pattern and regional morphostructure at Melka Kunture (Upper Awash, Ethiopia). In: Chavaillon J, Piperno M, editors. Studies on the Early Paleolithic site of Melka Kunture, Ethiopia. Florence: Istituto Italiano di Preistoria e Protostoria. p 83-92.

Bastir M, O’Higgins P, Rosas A. 2007. Facial ontogeny in Neanderthals and modern humans. Proc R Soc B 274:1125-1132.

Bayle P. 2008. Proportions des tissus des dents déciduales chez deux individus de Dordogne (France): l'enfant Néanderthalien du Roc de Marsal et le spécimen du Paléolithique supérieur final de La Madeleine. Bull Mém Soc Anthropol Paris 20:151-163.

Bayle P, Braga J, Mazurier A, Macchiarelli R. 2009a. Dental developmental pattern of the Neanderthal child from Roc de Marsal: a high-resolution 3D analysis. J Hum Evol 56:66-75. 
Bayle P, Braga J, Mazurier A, Macchiarelli R. 2009b. High-resolution assessment of the dental developmental pattern and characterization of tooth tissue proportions in the Late Upper Paleolithic child from La Madeleine, France. Am J Phys Anthropol 138:493-498.

Bayle P, Macchiarelli R, Trinkaus E, Duarte C, Mazurier A, Zilhão J. 2010. Dental maturational pattern and dental tissue proportions in the early Upper Paleolithic child from Abrigo do Lagar Velho, Portugal. Proc Natl Acad Sci USA 107:1338-1342.

Beaudet A, Zanolli C, Engda Redae B, Endalamaw M, Braga J, Macchiarelli R. 2015. A new cercopithecoid dentognathic specimen attributed to Theropithecus from the late Early Pleistocene (c. $1 \mathrm{Ma}$ ) deposits of Simbiro, at Melka Kunture, Ethiopian highlands. CR Palevol 14:657-669.

Begun DR. 2013. A Companion to Paleoanthropology. Chichester: Wiley-Blackwell.

Bennett MR, Harris JWK, Richmond BG, Braun DR, Mbua E, Kiura P, Olago D, Kibunjia M, Omuombo C, Behrensmeyer AK, Huddart D, Gonzalez S. 2009. Early hominin foot morphology based on 1.5-million-year old footprints from Ileret, Kenya. Science 323:11971201.

Bermúdez de Castro JM, Martín-Francés L, Modesto-Mata M, Martínez de Pinillos M, MartinónTorres M, García-Campos C, Miguel Carretero J. 2016. Brief Communication: Virtual reconstruction of the Early Pleistocene mandible ATD6-96 from Gran Dolina-TD6-2 (Sierra De Atapuerca, Spain). Am J Phys Anthropol 159:729-736.

Bermúdez de Castro JM, Martinón-Torres M, Prado L, Gómez-Robles A, Rosell J, López-Polín L, Arsuaga JL, Carbonell E. 2010. New immature hominin fossil from European Lower Pleistocene shows the earliest evidence of a modern human dental development pattern. Proc Natl Acad Sci USA 107:11739-11744.

Bermúdez de Castro JM, Pérez-González A, Martinón-Torres M, Gómez-Robles A, Rosell J, Prado L, Sarmiento S, Carbonell E. 2008. A new early Pleistocene hominin mandible from Atapuerca-TD6, Spain. J Hum Evol 55:729-735.

Bermúdez de Castro JM, Rosas A, Nicolás ME. 1999. Dental remains from Atapuerca-TD6 (Gran Dolina site, Burgos, Spain). J Hum Evol 37:523-566.

Bocherens H, Koch PL, Mariotti A, Geraads D, Jaeger JJ. 1996. Isotopic biogeochemistry $\left({ }^{13} \mathrm{C}\right.$, ${ }^{18} \mathrm{O}$ ) of mammalian enamel from African Pleistocene hominid sites. Palaios 11:306-318. 
Bonnefille R. 1976. Végétations et climats des temps oldowayens et acheuléens à Melka-Kunturé (Ethiopie). In: CNRS, editor. L'Ethiopie avant l'histoire. Paris: CNRS. p 55-71.

Braga J, Heuzé Y. 2007. Quantifying variation in human dental developmental sequences. An Evo-Devo perspective. In: Bailey SE, Hublin JJ, editors. Dental perspectives on human evolution: state of the art research in dental anthropology. Berlin: Springer. p 247-261.

Carretero JM, Haile-Selassie Y, Rodriguez L, Arsuaga JL. 2009. A partial distal humerus from the Middle Pleistocene deposits at Bodo, Middle Awash, Ethiopia. Anthropol Sci 117:19-31.

Chavaillon J, Berthelet A. 2004. The archaeological sites of Melka Kunture. In: Chavaillon J, Piperno M, editors. Studies on the Early Paleolithic site of Melka Kunture, Ethiopia. Florence: Istituto Italiano di Preistoria e Protostoria. p 25-80.

Chavaillon J, Brahimi C, Coppens Y. 1974. Première découverte d'Hominidé dans l'un des sites acheuléens de Melka Kunturé (Ethiopie). CR Acad Sc Paris 278:3299-3302.

Chavaillon J, Chavaillon N, Coppens Y, Senut B. 1977. Présence d'Hominidé dans le site oldowayen de Gomboré I à Melka Kunturé, Ethiopie. CR Acad Sc Paris 285:961-963.

Chavaillon J, Chavaillon N, Hours F, Piperno M. 1979. From Oldowan to middle Stone Age at Melka Kunture: understanding cultural changes. Quaternaria 21:87-114.

Chavaillon J, Coppens Y. 1986. Nouvelle découverte d'Homo erectus à Melka Kunturé (Ethiopie). CR Acad Sc Paris 303:99-104.

Chavaillon J, Hours F, Coppens Y. 1987. Découverte de restes humains fossiles associés à un outillage acheuléen final à Melka-Kunturé (Ethiopie). CR Acad Sc Paris 304:539-542.

Chavaillon J, Piperno M. 1975. Garba IV, site paléolithique ancien de Melka-Konturé. Bull Soc Préhist Franç 72:134-138.

Chavaillon J, Piperno M. 2004a. Studies on the Early Paleolithic site of Melka Kunture, Ethiopia. Florence: Instituto Italiano di Preistoria e Protostoria.

Chavaillon J, Piperno M. 2004b. History of excavations at Melka Kunture. In: Chavaillon J, Piperno M, editors. Studies on the Early Paleolithic site of Melka Kunture, Ethiopia. Florence: Instituto Italiano di Preistoria e Protostoria. p 3-23.

Chavaillon J, Taieb M. 1968. Stratigraphie du Quaternaire de Melka-Kunturé, vallée de l'Awash, Ethiopie. Premiers résultats. CR Acad Sci Paris 266:1210-1212. 
Condemi S. 2004. The Garba IV E mandible. In: Chavaillon J, Piperno M, editors. Studies on the Early Paleolithic site of Melka Kunture, Ethiopia. Florence: Istituto Italiano di Preistoria e Protostoria. p 687-701.

Coppens Y. 2004. The hominids of Melka Kunture. Some general reflections. In: Chavaillon J, Piperno M, editors. Studies on the Early Paleolithic site of Melka Kunture, Ethiopia. Florence: Istituto Italiano di Preistoria e Protostoria. p 685-686.

Daegling DJ. 1989. Biomechanics of cross-sectional size and shape in the hominoid mandibular corpus. Am J Phys Anthropol 80:91-106.

Daegling DJ, Grine FE. 1991. Compact bone distribution and biomechanics of early hominid mandibles. Am J Phys Anthropol 86:321-339.

Daegling DJ, Hotzman JL. 2003. Functional significance of cortical bone distribution in anthropoid mandibles: an in vitro assessment of bone strain under combined loads. Am J Phys Anthropol 122: 38-50.

Dean MC. 1987. The dental developmental status of six East African juvenile fossil hominids. J Hum Evol 16:197-213.

Dean MC. 2012. Daily rates of dentine formation and root extension rates in Paranthropus boisei, KNM-ER 1817, from Koobi Fora, Kenya. In: Reynolds SC, Gallagher A, editors. African Genesis. Perspectives on Hominin Evolution. Cambridge: Cambridge University Press. p 268-279.

Dean MC. 2016. Measures of maturation in early fossil hominins: events at the first transition from australopiths to early Homo. Phil Trans R Soc B 20150234 (http://dx.doi.org/10.1098/rstb.2015.023).

Dean MC, Cole TJ. 2013. Human life history evolution explains dissociation between the timing of tooth eruption and peak rates of root growth. PLoS ONE 8:e54534 (doi:10.1371/journal.pone.0054534).

Dean MC, Leakey MG, Reid D, Schrenk F, Schwartz GT, Stringer C, Walker A. 2001. Growth processes in teeth distinguish modern humans from Homo erectus and earlier hominins. Nature 414:628-631.

Dean MC, Smith BH. 2009. Growth and development in the Nariokotome youth, KNM-WT 15000. In: Grine FE, Fleagle JG, Leakey RE, editors. The First Humans: Origin of the Genus Homo. New York: Springer. p 101-120. 
Dean MC, Wood B. 2003. A digital radiographic atlas of great apes skull and dentition. In: Bondioli L, Macchiarelli R, editors. Digital Archives of Human Paleobiology. Milan: ADS Solutions (CD-ROM).

Demes B, Preuschoft H, Wolff JEA. 1984. Stress-strength relationships in the mandibles of hominoids. In: Chivers DJ, Wood BA, Bilsborough A, editors. Food Acquisition and Processing in Primates. New York: Plenum. p 369-390.

Demirjian A, Goldstein H, Tanner JM. 1973. A new system of dental age assessment. Hum Biol 45:211-227.

Di Vincenzo F, Rodriguez L, Carrettero JM, Collina C, Geraads D, Piperno M, Manzi G. 2015. The massive fossil humerus from the Oldowan horizon of Gombore I, Melka Kunture (Ethiopia, >1.39 Ma). Quat Sc Rev 122:207-221.

Fajardo RJ, Ryan TM, Kappelman J. 2002. Assessing the accuracy of high resolution X-ray computed tomography of primate trabecular bone by comparisons with histological sections. Am J Phys Anthropol 118:1-10.

Friis I, Demissew S, van Breugel P. 2011. Atlas of potential vegetation of Ethiopia. Addis Ababa: Addis Ababa University Press.

Fukase H. 2007. Functional significance of bone distribution in the human mandibular symphysis. Anthrop Sci 115:55-62.

Fukase H, Suwa G. 2008. Growth-related changes in prehistoric Jomon and modern Japanese mandibles with emphasis on cortical bone distribution. Am J Phys Anthropol 136:441-454.

Gallotti R. 2013. An older origin for the Acheulean at Melka Kunture (Upper Awash, Ethiopia): techno-economic behaviours at Garba IVD. J Hum Evol 65:594-620.

Gallotti R, Collina C, Raynal J-P, Kieffer G, Geraads D, Piperno M. 2010. The early Middle Pleistocene site of Gombore II (Melka Kunture, Upper Awash, Ethiopia) and the issue of Acheulean bifacial shaping strategies. Afr Archaeol Rev 27:291-322.

Gallotti R., Mussi M. 2015. The unknown Oldowan: 1.7-million-year-old standardized obsidian small tools from Garba IV, Melka Kunture, Ethiopia. PLoS ONE 10(12): e0145101 (doi:10.1371/journal.pone.0145101).

Gallotti R, Raynal J-P, Geraads D, Mussi M. 2014. Garba XIII (Melka Kunture, Upper Awash, Ethiopia): a new Acheulean site of the late Lower Pleistocene. Quat Int 343:17-27. 
Geraads D. 1979. La faune des gisements de Melka-Kunturé (Ethiopie): artiodactyles, primates. Abbay 10:21-49.

Geraads D. 1985. La faune des gisements de Melka-Kunturé (Ethiopie). In: Fondation SingerPolignac, editor. L'environnement des Hominidés au Plio-Pléistocène. Paris: Masson. p 165174.

Geraads D, Alemseged Z, Reed D, Wynn J, Roman DC. 2004b. The Pleistocene fauna (other than Primates) from Asbole, lower Awash Valley, Ethiopia, and its environmental and biochronological implications. Geobios 37:697-718.

Geraads D, Eisenmann V, Petter G. 2004a. The large mammal fauna of the Oldowan sites of Melka Kunture. In: Chavaillon J, Piperno M, editors. Studies on the Early Paleolithic site of Melka Kunture, Ethiopia. Florence: Istituto Italiano di Preistoria e Protostoria. p 169-192.

Gómez-Robles A, Bermúdez de Castro JM, Martinón-Torres M, Prado-Simón L. 2011. Crown size and cusp proportions in Homo antecessor upper first molars. A comment on Quam et al. 2009. J Anat 218:258-262.

Gómez-Robles A, Martinón-Torres M, Bermúdez de Castro JM, Margvelashvili A, Bastir M, Arsuaga JL, Pérez-Pérez A, Estebaranz F, Martínez LM. 2007. A geometric morphometric analysis of hominin upper first molar shape. J Hum Evol 53:272-285.

Grine FE, Franzen JL. 1994. Fossil hominid teeth from the Sangiran Dome (Java, Indonesia). Cour Forsch-Inst Senckenberg 171:75-103.

Gröning F, Liu J, Fagan MJ, O'Higgins P. 2009. Validating a voxel-based finite element model of a human mandible using digital speckle pattern interferometry. J Biomech 42:1224-1229.

Henke W, Tattersall I. 2015. Handbook of Paleoanthropology. $2^{\text {nd }}$ ed. Heidelberg: Springer.

Hillson S. 2005. Teeth. Cambridge: Cambridge University Press.

Hivernel-Guerre F. 1976. Les industries du Late Stone Age dans la région de Melka-Kunturé. In: Berhanou A, Chavaillon J, Sutton R, editors. Actes du VII Congrès de Préhistoire et d'Etudes du Quaternaire, 1971. Addis-Abeba. p 93-98.

Kaifu Y, Aziz F, Baba H. 2005. Hominid mandibular remains from Sangiran: 1952-1986 collection. Am J Phys Anthropol 128:497-519.

Kebede M, Yirdaw E, Luukkanen O, Lemenih M. 2013. Plant community analysis and effect of environmental factors on the diversity of woody species in the moist Afromontane forest of Wondo Genet, South Central Ethiopia. Biodiv Res Conserv 29:63-80. 
Kieffer G, Raynal J-P, Bardin G. 2002. Cadre structural et volcanologiques des sites du Paléolithique ancien de Melka Kunture (Awash, Ethiopie): premiers résultats. In: Raynal J-P, Albore-Livadie C, Piperno M, editors. Hommes et volcans. De l'éruption à l'objet. Proc. XIV UISPP Congress, Liège, 2001. Liège: Les Dossiers de l'Archéo-Logis 2. p 77-92.

Kieffer G, Raynal J-P, Bardin G. 2004. Volcanic markers in coarse alluvium at Melka Kunture (Upper Awash, Ethiopia). In: Chavaillon J, Piperno M, editors. Studies on the Early Paleolithic site of Melka Kunture, Ethiopia. Florence: Istituto Italiano di Preistoria e Protostoria. p 93-101.

Krovitz, GE, Thompson, JL, Nelson, AJ. 2003. Hominid growth and development from australopithecines to Middle Pleistocene Homo. In: Thompson JL, Krovitz GE, Nelson AJ, editors. Patterns of Growth and Development in the Genus Homo. Cambridge: Cambridge University Press. p 271-292.

Kupczik K, Hublin JJ. 2010. Mandibular molar root morphology in Neanderthals and Late Pleistocene and recent Homo sapiens. J Hum Evol 59:525-541.

Leakey MG, Spoor F, Dean MC, Feibel CS, Antón SC, Kiarie C, Leakey LN. 2012. New fossils from Koobi Fora in northern Kenya confirm taxonomic diversity in early Homo. Nature 488:201-204.

Leakey REF, Wood BA. 1973. New evidence of the genus Homo from East Rudolf, Kenya (II). Am J Phys Anthropol 39:355-368.

Leakey REF, Wood BA. 1974. New evidence of the genus Homo from East Rudolf, Kenya (IV). Am J Phys Anthropol 41:237-244.

Liversidge HM. 2010. Demirjian stage tooth formation results from a large group of children. Dent Anthropol 23:16-24.

Liversidge HM, Molleson T. 2004. Variation in crown and root formation and eruption of human deciduous teeth. Am J Phys Anthropol 123:172-180.

Lordkipanidze D, Ponce de León MS, Margvelashvili A, Rak Y, Rightmire GP, Vekua A, Zollikofer CPE. 2013. A complete skull from Dmanisi, Georgia, and the evolutionary biology of early Homo. Science 342:326-331.

Macchiarelli R, Bayle P, Bondioli L, Mazurier A, Zanolli C. 2013. From outer to inner structural morphology in dental anthropology. The integration of the third dimension in the visualization and quantitative analysis of fossil remains. In: Scott GR, Irish JD, editors. Anthropological 
perspectives on tooth morphology. Genetics, evolution, variation. Cambridge: Cambridge University Press. p 250-277.

Macchiarelli R, Bondioli L, Debénath A, Mazurier A, Tournepiche J-F, Birch W, Dean C. 2006. How Neanderthal molar teeth grew. Nature 444:748-751.

Maddux DS, Ward CV, Brown FH, Plavcan M, Manthi FK. 2015. A 750,000 year old hominin molar from the site of Nadung'a, West Turkana, Kenya. J Hum Evol 80:179-183.

Martinón-Torres M, Bermúdez de Castro JM, Gómez-Robles A, Margvelshvill A, Prado L, Lordkipanidze D, Vekua A. 2008. Dental remains from Dmanisi (Republic of Georgia): morphological analysis and comparative study. J Hum Evol 55:249-273.

McDougall I, Brown FH, Vasconcelos PM, Cohen BE, Thiede DS, Buchanan MJ. 2012. New single crystal ${ }^{40} \mathrm{Ar} /{ }^{39} \mathrm{Ar}$ ages improve time scale for deposition of the Omo Group, OmoTurkana Basin, East Africa. J Geol Soc London 169:213-226.

Moggi-Cecchi J, Grine FE, Tobias PV. 2006. Early hominid dental remains from Members 4 and 5 of the Sterkfontein Formation (1966-1996 excavations): Catalogue, individual associations, morphological descriptions and initial metrical analysis. J Hum Evol 50:239-328.

Moggi-Cecchi J, Menter C, Boccone S, Keyser A. 2010. Early hominin dental remains from the Plio-Pleistocene site of Drimolen, South Africa. J Hum Evol 58:374-405.

Moggi-Cecchi J, Tobias PV, Beynon A. 1998. The mixed dentition and associated skull fragments of a juvenile fossil hominid from Sterkfontein, South Africa. Am J Phys Anthropol 106:425-465.

Morgan LE, Renne PR, Kieffer G, Piperno M, Gallotti R, Raynal J-P. 2012. A chronological framework for a long and persistent archaeological record: Melka Kunture, Ethiopia. J Hum Evol 62:104-115.

Mussi M, Altamura F, Macchiarelli R, Melis RT, Spinapolice EE. 2014. Garba III (Melka Kunture, Ethiopia): a MSA site with archaic Homo sapiens remains revisited. Quat Int 343:2839.

Mussi M, Bonnefille R, Gallotti R. 2015. Melka Kunture (Upper Awash, Ethiopian plateau): the earliest human settlement of a high mountain system. Proc Europ Soc Study Hum Evol 5:167 (abstract).

NESPOS Database. 2015. Neanderthal studies professional online service (http://www.nespos.org). 
Olejniczak AJ, Smith TM, Feeney RNM, Macchiarelli R, Mazurier A, Bondioli L, Rosas A, Fortea J, de la Rasilla M, Garcia-Tabernero A, Radovčić J, Skinner MM, Toussaint M, Hublin JJ. 2008. Dental tissue proportions and enamel thickness in Neandertal and modern human molars. J Hum Evol 55:12-23.

Oussedik O. 1976. Site de Simburro III à Melka-Kunturé. In: CNRS, editor. L'Ethiopie avant l'histoire. Paris: CNRS. p 27-33.

Piperno M, Bulgarelli GM. 2004. The site of Garba IV. Excavations 1973-1982. In: Chavaillon J,

Piperno M, editors. Studies on the Early Paleolithic site of Melka Kunture, Ethiopia. Florence: Istituto Italiano di Preistoria e Protostoria. p 449-458.

Piperno M, Bulgarelli-Piperno GM. 1975. First approach to the ecological and cultural significance of the early Palaeolithic occupation site of Garba IV at Melka-Kunture (Ethiopia). Quaternaria 18:347-382.

Piperno M, Bulgarelli GM, Gallotti R. 2004a. The site of Garba IV. The lithic industry of level C.

Typological and technological study. In: Chavaillon J, Piperno M, editors. Studies on the Early Paleolithic site of Melka Kunture, Ethiopia. Florence: Istituto Italiano di Preistoria e Protostoria. p 459-468.

Piperno M, Bulgarelli GM, Gallotti R. 2004b. The site of Garba IV. The lithic industry of Level D. Débitage and tools on flake. In: Chavaillon J, Piperno M, editors. Studies on the Early Paleolithic site of Melka Kunture, Ethiopia. Florence: Istituto Italiano di Preistoria e Protostoria. p 469-544.

Piperno M, Bulgarelli GM, Gallotti R. 2004c. The site of Garba IV. The lithic industry of level D. Tools on pebble and percussion material. In: Chavaillon J, Piperno M, editors. Studies on the Early Paleolithic site of Melka Kunture, Ethiopia. Florence: Istituto Italiano di Preistoria e Protostoria. p 545-580.

Piperno M, Bulgarelli GM, Gallotti R. 2004d. The site of Garba IV. The test trenches A and B and the sounding in level E. In: Chavaillon J, Piperno M, editors. Studies on the Early Paleolithic site of Melka Kunture, Ethiopia. Florence: Istituto Italiano di Preistoria e Protostoria. p 581-587.

Piperno M, Collina C, Gallotti R, Raynal J-P, Kieffer G, Le Bourdonnec F-X, Poupeau G, Geraads D. 2009. Obsidian exploitation and utilization during the Oldowan at Melka Kunture 
(Ethiopia). In: Hovers E, Braun DR, editors. Interdisciplinary approaches to the Oldowan. Dordrecht: Springer. p 111-128.

Ponce de León MS, Zollikofer CPE. 2001. Neanderthal cranial ontogeny and its implications for late hominid diversity. Nature 412:534-538.

Profico A, Di Vincenzo F, Gagliardi L, Piperno M, Manzi G. 2016. Filling the gap. Human cranial remains from Gombore II (Melka Kunture, Ethiopia, ca. $850 \mathrm{ka}$ ) and the origin of Homo heidelbergensis. J Anthropol Sci 94:1-24.

Puymerail L, Bondioli L, Engda B, Mazurier A, Macchiarelli R. 2014. The Early Pleistocene human distal humerus from Gombore I, Melka Kunture (Upper Awash basin, Ethiopia). Cortical bone topography and structural organization. Int Symp The Afr Hum Foss Rec. Toulouse:15-16 (http://www.tahfr.cnrs.fr) (abstract).

Raynal J-P, Kieffer G. 2004. Lithology, dynamism and volcanic successions at Melka Kunture (Upper Awash, Ethiopia). In: Chavaillon J, Piperno M, editors. Studies on the Early Paleolithic site of Melka Kunture, Ethiopia. Florence: Istituto Italiano di Preistoria e Protostoria. p 111-135.

Raynal J-P, Kieffer G, Bardin G. 2004. Garba IV and the Melka Kunture Formation. A preliminary lithostratigraphic approach. In: Chavaillon J, Piperno M, editors. Studies on the Early Paleolithic site of Melka Kunture, Ethiopia. Florence: Istituto Italiano di Preistoria e Protostoria. p 137-166.

Robson SL, Wood B. 2008. Hominin life history: reconstruction and evolution. J Anat 212:394425.

Sabatier M. 1980-82. Les rongeurs des sites pléistocènes de Melka-Kunturé (Ethiopie). Abbay 11:45-71.

Schneider CA, Rasband WS, Eliceiri KW. 2012. NIH Image to ImageJ: 25 years of image analysis. Nature Meth. 9:671-675.

Schwartz JH, Tattersall I. 2003. The Human Fossil Record. Volume Two. Craniodental Morphology of Genus Homo (Africa and Asia). Hoboken: Wiley-Liss.

Scott GR, Turner CG II. 1997. The anthropology of modern human teeth. Dental morphology and its variation in recent human populations. Cambridge: Cambridge University Press.

Senut B. 1979. Comparaison des Hominidés de Gomboré IB et de Kanapoi: deux pièces du genre Homo? Bull Mém Soc Anthrop Paris 6:111-117. 
Skinner MF, Sperber GH. 1982. Atlas of Radiographs of Early Man. New York: A.R. Liss.

Smith HB. 1984. Patterns of molar wear in hunter-gatherers and agriculturalists. Am J Phys Anthropol 63:39-56.

Smith TM, Tafforeau P, Le Cabec A, Bonnin A, Houssaye A, Pouech J, Moggi-Cecchi J, Manthi F, Ward C, Makaremi M, Menter C. 2015. Dental ontogeny in Pliocene and Early Pleistocene hominins. PLoS ONE 10: e0118118 (doi:10.1371/journal.pone.0118118).

Spoor F, Zonneveld F, Macho GA. 1993. Linear measurements of cortical bone and dental enamel by computed tomography: applications and problems. Am J Phys Anthropol 91:469484.

Suwa G, Asfaw B, Beyene Y, White TD, Katoh S, Nagaoka S, Nakaya H, Uzawa K, Renne P, WoldeGabriel G. 1997. The first skull of Australopithecus boisei. Nature 389:489-492.

Suwa G, Asfaw B, Haile-Selassie Y, White T, Katoh S, Woldegabriel G, Hart WK, Nakaya H, Beyene Y. 2007. Early Pleistocene Homo erectus fossils from Konso, southern Ethiopia. Anthropol Sci 115:133-151.

Taieb M. 1967. Considérations géologiques préliminaires sur le Quaternaire de la vallée de l'Aouache. Ann Ethiopie 7:3-8.

Taieb M. 1971. Les dépôts quaternaires sédimentaires de la vallée de l'Aouache et leurs relations avec la néotectonique cassante du rift. Quaternaria 15:351-365.

Tamrat E, Thouveny N, Taieb M, Brugal JP. 2014. Magnetostratigraphic study of the Melka Kunture archaeological site (Ethiopia) and its chronological implications. Quat Int 343:5-16.

Towle IE, Irish JD, de Groote I. 2016. Enamel defects in Paranthropus robustus relative to other South African hominins. Am J Phys Anthropol 159 S62:316 (abstract).

Turner CG II, Nichol CR, Scott GR. 1991. Scoring procedures for key morphological traits of the permanent dentition: the Arizona State University Dental Anthropology System. In: Kelley MA, Larsen CS, editors. Advances in dental anthropology. New York: Wiley-Liss. p 13-31.

Villmoare B, Kimbel WH, Seyoum C, Campisano CJ, DiMaggio E, Rowan J, Braun DR, Arrowsmith JR, Reed KE. 2015. Early Homo at 2.8 Ma from Ledi-Geraru, Afar, Ethiopia. Science 347:1352-1355.

Vieland V. 1998. Bayesian linkage analysis, or: how I learned to stop worrying and love the posterior probability of linkage. Am J Hum Genet 63:947-954. 
Walker A, Leakey R. 1993. The skull. In: Walker A, Leakey R, editors. The Nariokotome Homo erectus skeleton. Cambridge, MA: Harvard University Press. p 63-96.

Widianto H. 1993. Unité et diversité des hominidés fossiles de Java: présentation de restes humains inédits. PhD dissertation. Paris: Muséum national d'Histoire naturelle.

Will M, Stock JT. 2015. Spatial and temporal variation of body size among early Homo. J Hum Evol 82:15-33.

Wood B. 1991. Koobi Fora research project, Vol.4: hominid cranial remains from Koobi Fora. Oxford: Clarendon Press.

Wood B, Leakey M. 2011. The Omo-Turkana Basin fossil hominins and their contribution to our understanding of human evolution in Africa. Evol Anthropol 20:264-292.

Zanolli C. 2013. Additional evidence for morpho-dimensional tooth crown variation in a new Indonesian H. erectus sample from the Sangiran Dome (Central Java). PLoS ONE 8:e67233 (doi: 10.1371/journal.pone.0067233).

Zanolli C, Bondioli L, Coppa A, Dean MC, Bayle P, Candilio F, Capuani S, Dreossi D, Fiore I, Frayer DW, Libsekal Y, Mancini L, Rook L, Medin Tekle T, Tuniz C, Macchiarelli R. 2014b. The late Early Pleistocene human dental remains from Uadi Aalad and Mulhuli-Amo (Buia), Eritrean Danakil: macromorphology and microstructure. J Hum Evol 74:96-113.

Zanolli C, Bondioli L, Mancini L, Mazurier A, Widianto H, Macchiarelli R. 2012. Two human fossil deciduous molars from the Sangiran Dome (Java, Indonesia): outer and inner morphology. Am J Phys Anthropol 147:472-481.

Zanolli C, Dean MC, Condemi S, Assefa Y, Bayle P, Coppa A, Endalamaw M, Macchiarelli R. 2014a. The Early Pleistocene infant partial mandible Garba IV E, from Melka Kunture, Ethiopia. A CT-based 3D investigation of its inner structure. Int Symp The Afr Hum Foss Rec. Toulouse:20-21 (http://www.tahfr.cnrs.fr) (abstract).

Zilberman U, Smith P, Condemi S. 2004a. Evidence for a genetic disorder affecting tooth formation in the Garba IV child. In: Chavaillon J, Piperno M, editors. Studies on the Early Paleolithic site of Melka Kunture, Ethiopia. Florence: Istituto Italiano di Preistoria e Protostoria. p 703-713.

Zilberman U, Smith P, Piperno M, Condemi S. 2004b. Evidence of amelogenesis imperfecta in an early African Homo erectus. J Hum Evol 46:647-653. 


\section{CAPTIONS FOR FIGURES}

Fig. 1. The right mandibular specimen GAR IVE. The original specimen in lateral (A), internal (B), and superior (C) views; a CT-based virtual section passing approximatively across its mid portion (D); the 3D rendering of the bone (in semi-transparency) and the in situ tooth elements $(\mathbf{E})$, where the dotted polygon at the base of the P3 highlights the outer outline of the hole opening into the P3 crypt which erased the foramen mentale (see Condemi, 2004); the virtually extracted tooth elements $(\mathbf{F})$, where the arrow indicates a mesiodistal fracture running along the P3. In all images but $\mathbf{B}$, posterior is to the left. Scale bar, $5 \mathrm{~mm}$.

Fig. 2. (A) Inner structural organization of four mandibular bodies of immature individuals virtually sectioned buccolingually across the dm2. From left to right: GAR IVE, the Neanderthal from Roc de Marsal (RdM; Bayle et al., 2009a), the Upper Paleolithic human from La Madeleine (LM4; Bayle et al., 2009b), and an extant human child (EH, spec. EH-UdP; Bayle et al., 2010). The lateral (buccal) aspect of the corpus is systematically to the left. The dotted lines indicate the upper limit of the section considered for quantitative assessment. All images, but GAR IVE (CTbased), obtained from a $\mu$ CT record (NESPOS Database, 2015). (B) Cortical bone thickness distribution (in $\mathrm{mm}$ ) comparatively assessed across the bony sections shown above (portion below the dotted line). b, buccal; i, inferior; 1, lingual. Scale bar, $5 \mathrm{~mm}$.

Fig. 3. The virtually extracted and 3D rendered deciduous and permanent tooth elements of the mandibular specimen GAR IVE. Enamel and dentine appear in orange, the pulp cavity in cyan. b, buccal; d, distal; 1, lingual; m, mesial; o, occlusal. Scale bar, 5 mm.

Fig. 4. The two deciduous (dm1 and $\mathrm{dm} 2)$ and three permanent (I2, C and M1) tooth elements of the mandibular specimen GAR IVE visible from the outside shown in different perspectives. $b$, buccal; d, distal; i, inferior; 1, lingual; m, mesial; o, occlusal; ol, occlusolingual. Scale bar, 5 mm.

Fig. 5. Crown dimensions (MD and BL diameters, in $\mathrm{mm}$ ) of the deciduous second molar $(\mathrm{dm} 2, \mathbf{A})$, the permanent lateral incisor (I2, B; BL only), the permanent canine (C, $\mathbf{C}$; MD only) and the first permanent molar (M1, D) of the mandibular specimen GAR IVE (black star) compared with the average values of some Pleistocene and recent human specimens/samples. EUPH: European Upper Paleolithic humans; HA: H. antecessor; HEA: H. erectus/ergaster from East Africa; HEC: H. erectus from China; HEG: H. erectus from Georgia; HEJ: H. erectus from Java; HHA: African H. heidelbergensis; HHE: European H. heidelbergensis; HHR: H. habilisrudolfensis from East Africa; NEA: Neanderthals; NEEHS: Near Eastern early H. sapiens; RH: recent humans. The related data (sources, N, means, range, s.d.) are provided in the Supporting Information (Table S1). 

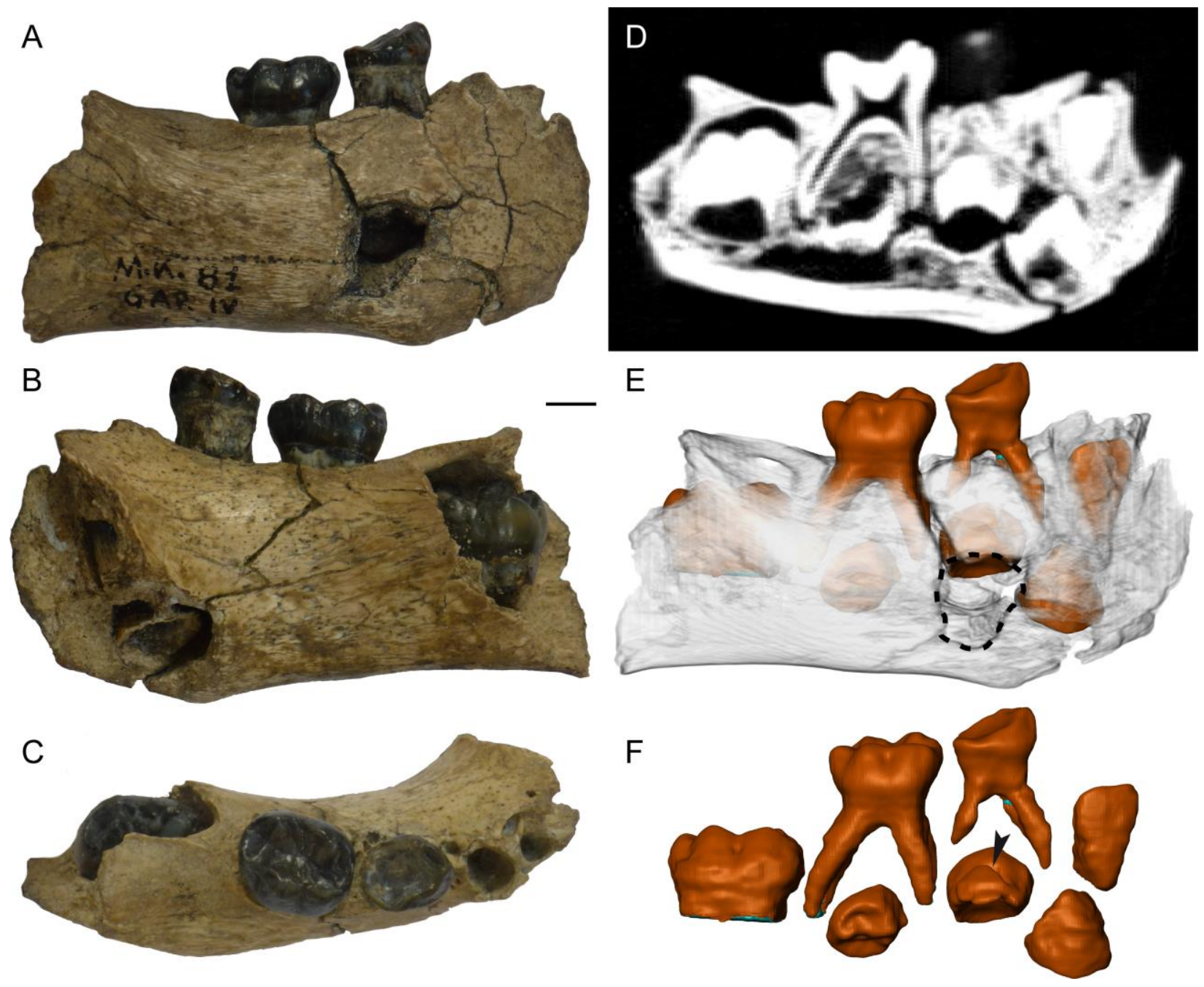

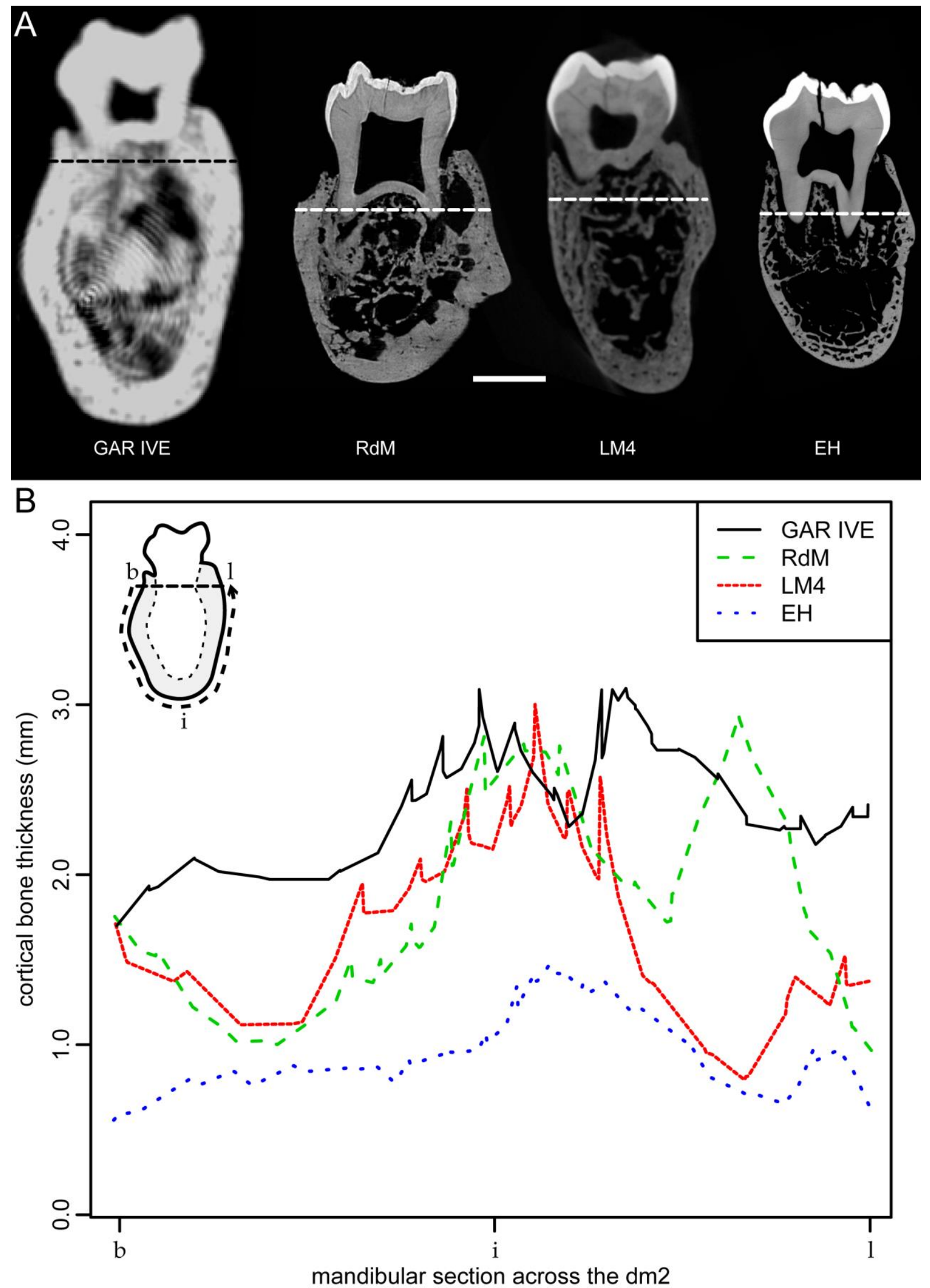

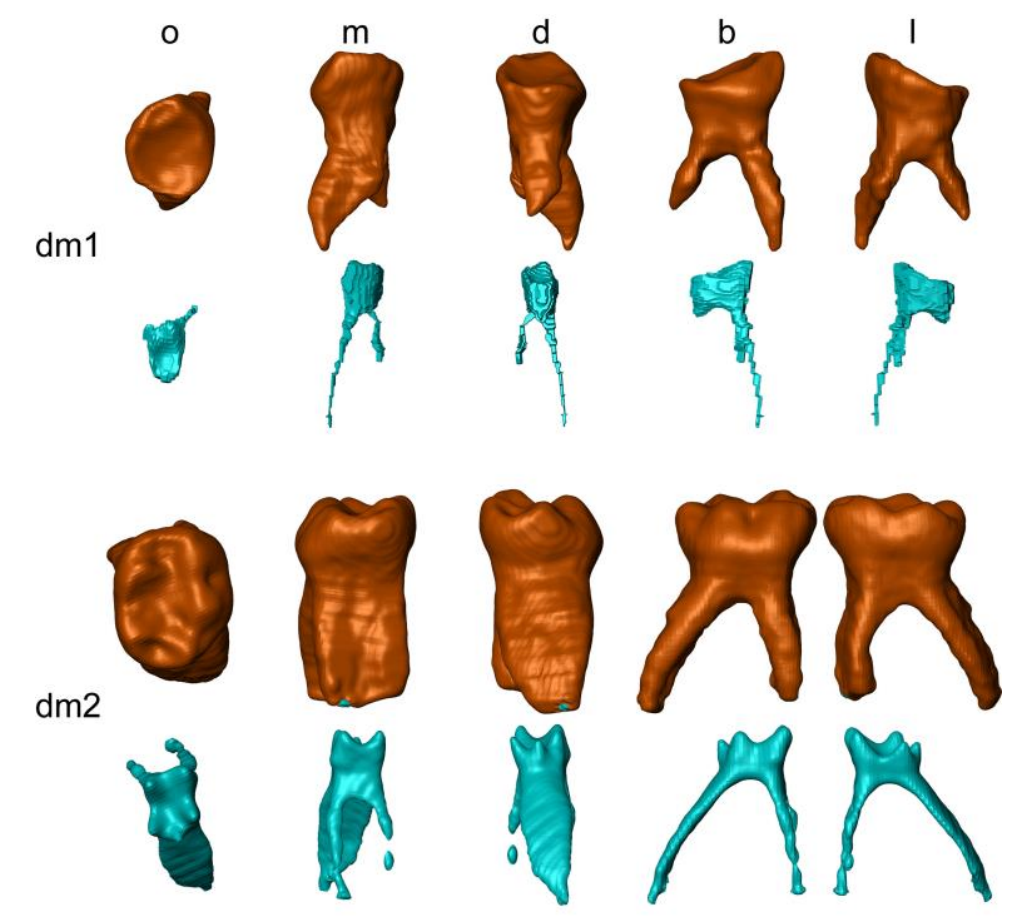

12

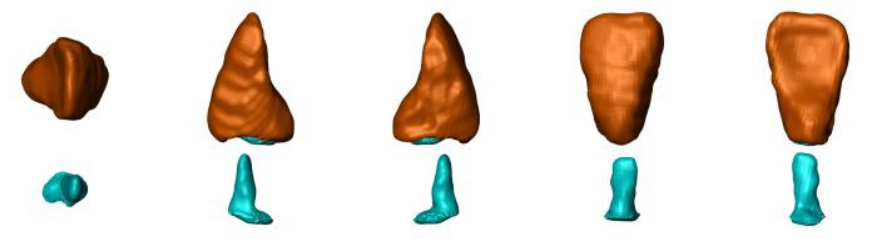

C

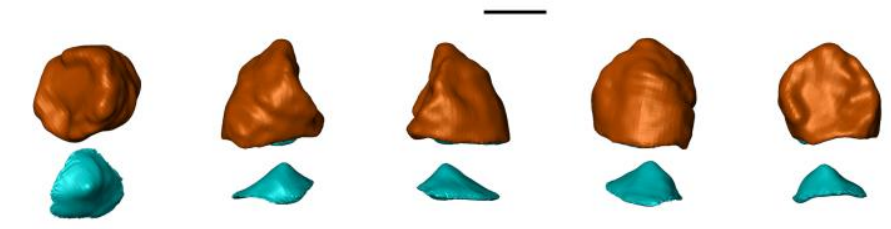

P3

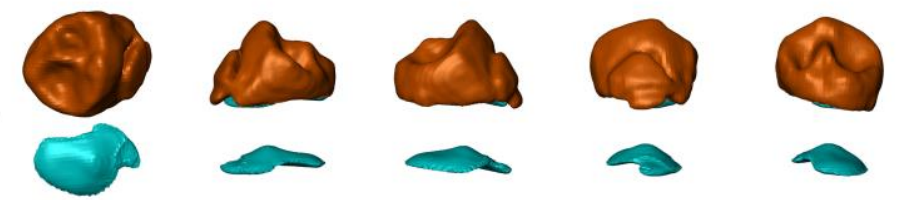

P4
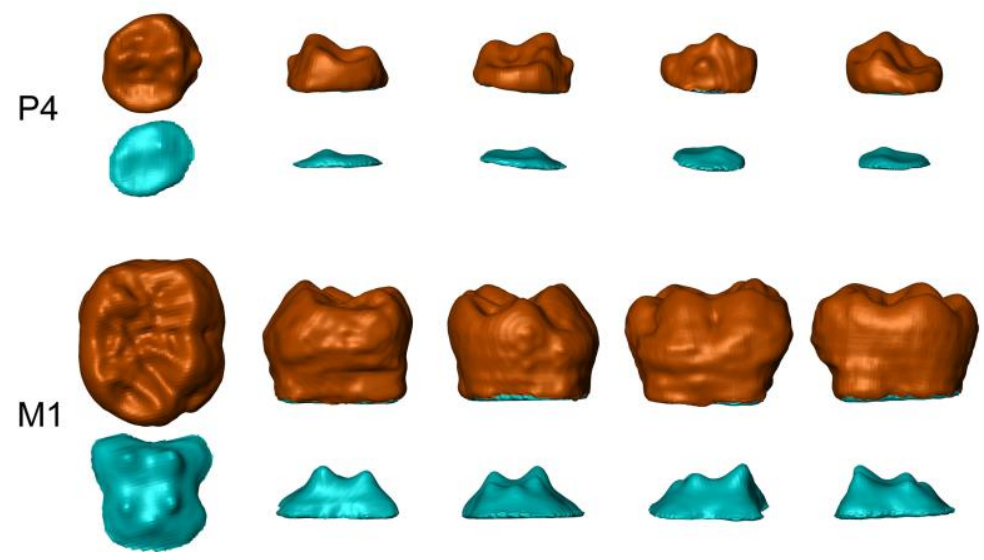

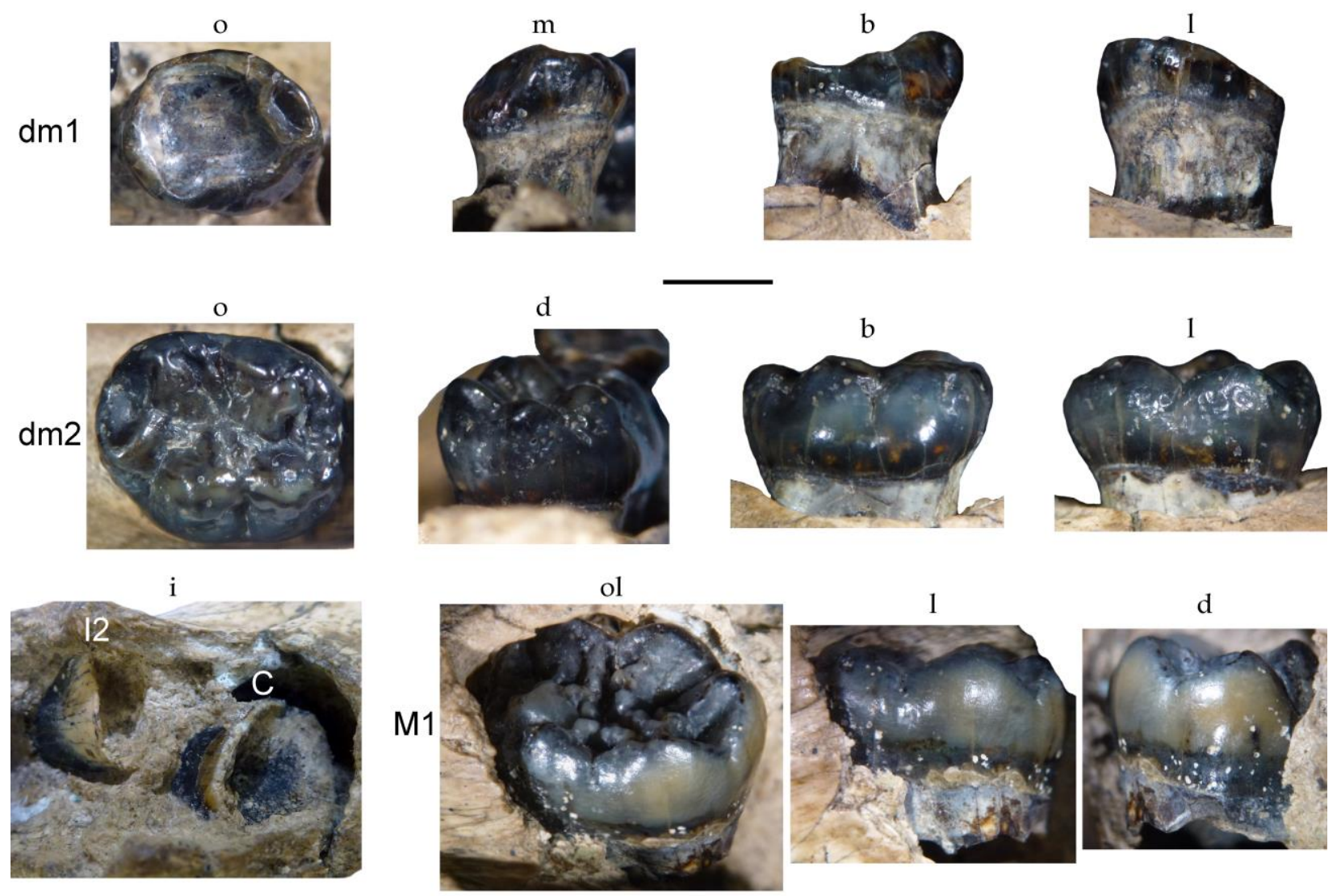

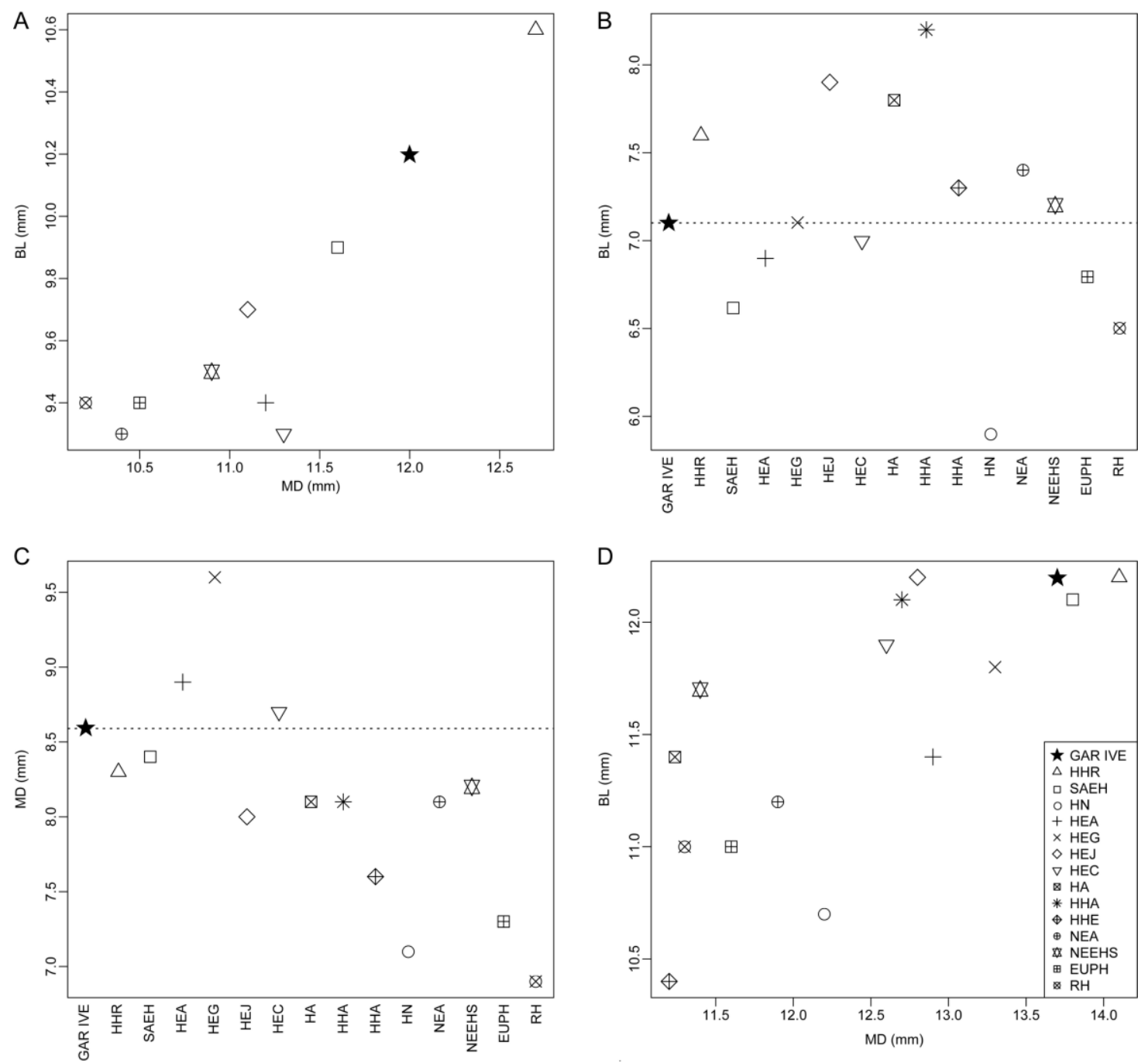
TABLE 1. Degree of maturation of the deciduous and permanent tooth elements of the mandibular specimen GAR IVE assessed following the scoring system established by Liversidge and Molleson (2004) and by Demirjian et al. (1973), respectively, modified and adapted by Bayle et al. (2009a).

\begin{tabular}{|c|c|c|}
\hline tooth & maturational & descriptive criteria of crown and root calcification \\
\hline $\mathrm{dm} 1$ & $\mathrm{r}$ & root resorption initiated $*$ \\
\hline $\mathrm{dm} 2$ & h1 & root length complete, with apical walls converging, but apexes are still open \\
\hline $\mathrm{I} 2$ & $\mathrm{D}$ & $\begin{array}{l}\text { crown complete down to the cemento-enamel junction and beginning of root } \\
\text { formation as a short spicule }\end{array}$ \\
\hline $\mathrm{C}$ & $\mathrm{C}$ & $\begin{array}{l}\text { crown formation is complete at the occlusal surface, and extension and } \\
\text { convergence towards the cervical region is seen }\end{array}$ \\
\hline P3 & $\mathrm{C}$ & $\begin{array}{l}\text { crown formation is complete at the occlusal surface, and extension and } \\
\text { convergence towards the cervical region is seen }\end{array}$ \\
\hline $\mathrm{P} 4$ & $\mathrm{~B}$ & $\begin{array}{l}\text { regularly outlined occlusal surface but extension towards the cervical region } \\
\text { barely visible }\end{array}$ \\
\hline M1 & $\mathrm{D}$ & $\begin{array}{l}\text { crown complete down to the cervix and beginning of root formation as a short } \\
\text { spicule }\end{array}$ \\
\hline
\end{tabular}

*As stated in the text, the $\mathrm{dm} 1$ exhibits an advanced wear degree, but this condition does not affect the assessment of the maturational stage which is based here on the degree of root resorption. 
TABLE 2. Results of the Bayesian analysis run for the permanent mineralization sequence of the mandibular specimen GAR IVE

\begin{tabular}{lrc}
\hline specimen (sequence) & GAR IVE \\
\hline N indiv. comparative sample & & 795 \\
$\mathrm{~N}$ theoretical combinations & & 30 \\
$\mathrm{~N}$ calculated combinations & & $30(100 \%)$ \\
$\mathrm{N}$ sequences $c f$. GAR IVE & & 4 \\
& $\mathrm{p}<0.25$ & 0 \\
probability balance $(\%)$ & $0.25 \leq \mathrm{p} \leq 0.75$ & 0 \\
& $\mathrm{p}>0.75$ & 100 \\
\hline
\end{tabular}


TABLE 3. Crown pulp volume (Vcp), total crown volume $(V c)$ and percent of coronal volume (Vcdp/Vc) assessed in the dm2 and $M 1$ of the mandibular specimen GAR IVE and compared with some Pleistocene and recent human specimens/samples

\begin{tabular}{|c|c|c|c|c|c|c|c|c|c|}
\hline & & $\mathrm{N}$ & $\mathrm{Vcp}\left(\mathrm{mm}^{3}\right)$ & $\begin{array}{c}\mathrm{dm} 2 \\
\mathrm{Vc}\left(\mathrm{mm}^{3}\right)\end{array}$ & $\mathrm{Vcp} / \mathrm{Vc}(\%)$ & $\mathrm{N}$ & Vcp & $\begin{array}{c}\mathrm{M} 1 \\
\mathrm{Vc}\left(\mathrm{mm}^{3}\right)\end{array}$ & $\mathrm{Vcp} / \mathrm{Vc}(\%)$ \\
\hline \multirow{2}{*}{\multicolumn{2}{|c|}{$\begin{array}{l}\text { GAR IVE } \\
\text { HEA }\end{array}$}} & & 17.2 & 381.5 & 4.5 & & 5.9 & 657.8 & 0.9 \\
\hline & & & & & & 1 & 15.4 & 593.5 & 2.6 \\
\hline \multicolumn{2}{|c|}{ HEJ } & 1 & & 382.8 & & & & & \\
\hline \multirow[t]{2}{*}{ NEA } & mean & 6 & 31.6 & 343.3 & 9.2 & 11 & 15.2 & 663.2 & 2.3 \\
\hline & range & & $26.1-37.1$ & $305.6-367.2$ & $8.5-10.5$ & & $3.7-37.0$ & $507.8-831.8$ & $0.5-5.6$ \\
\hline \multirow[t]{2}{*}{ EUPH } & mean & 3 & 16.1 & 318.2 & 5.0 & 1 & 40.7 & 590.1 & 6.9 \\
\hline & range & & $14.1-19.2$ & $298.2-343.5$ & $4.5-5.6$ & & & & \\
\hline \multirow[t]{2}{*}{ RH } & mean & 7 & 15.4 & 260.6 & 5.7 & 11 & 14.7 & 548.8 & 2.6 \\
\hline & range & & $6.4-38.3$ & 217.1-311.6 & $3.0-12.3$ & & $2.7-34.5$ & $442.7-770.7$ & $0.5-6.7$ \\
\hline
\end{tabular}

EUPH: European Upper Paleolithic humans (Bayle, 2008; Bayle et al., 2009b, 2010; NESPOS Database, 2015); HEA: $H$. erectus/ergaster from the Eritrean Danakil (Zanolli et al., 2014b); HEJ: H. erectus from Java (Zanolli et al., 2012); NEA: Neanderthals (Macchiarelli et al., 2006, 2013; Olejniczak et al., 2008; Bayle et al., 2009a, 2010; Kupczik and Hublin, 2010; Zanolli et al., 2012, 2014; NESPOS Database, 2015); RH: recent humans (Bayle, 2008; Olejniczak et al., 2008; Bayle et al., 2010; Zanolli et al., 2012, 2014; and original data). 